\title{
Challenges and Strategies in Ascribing Functions to Long Noncoding RNAs
}

\author{
Yang Zhao ${ }^{1} \mathbb{1}$, Hongqi Teng ${ }^{1}$, Fan Yao ${ }^{1}$, Shannon Yap ${ }^{1}$, Yutong Sun ${ }^{2} \mathbb{C}$ and Li Ma ${ }^{1,3, * \mathbb{C}}$ \\ 1 Department of Experimental Radiation Oncology, The University of Texas MD Anderson Cancer Center, \\ Houston, TX 77030, USA; YZhao18@mdanderson.org (Y.Z.); HTeng1@mdanderson.org (H.T.); \\ FYao@mdanderson.org (F.Y.); SSYap@mdanderson.org (S.Y.) \\ 2 Department of Molecular and Cellular Oncology, The University of Texas MD Anderson Cancer Center, \\ Houston, TX 77030, USA; YSun2@mdanderson.org \\ 3 UTHealth Graduate School of Biomedical Sciences, The University of Texas MD Anderson Cancer Center, \\ Houston, TX 77030, USA \\ * Correspondence: lma4@mdanderson.org; Tel.: +1-713-792-6590
}

Received: 12 April 2020; Accepted: 1 June 2020; Published: 3 June 2020

\begin{abstract}
Long noncoding RNAs (lncRNAs) are involved in many physiological and pathological processes, such as development, aging, immunity, and cancer. Mechanistically, lncRNAs exert their functions through interaction with proteins, genomic DNA, and other RNA, leading to transcriptional and post-transcriptional regulation of gene expression, either in cis or in trans; it is often difficult to distinguish between these two regulatory mechanisms. A variety of approaches, including RNA interference, antisense oligonucleotides, CRISPR-based methods, and genetically engineered mouse models, have yielded abundant information about lncRNA functions and underlying mechanisms, albeit with many discrepancies. In this review, we elaborate on the challenges in ascribing functions to lncRNAs based on the features of lncRNAs, including the genomic location, copy number, domain structure, subcellular localization, stability, evolution, and expression pattern. We also describe a framework for the investigation of lncRNA functions and mechanisms of action. Rigorous characterization of cancer-implicated lncRNAs is critical for the identification of bona fide anticancer targets.
\end{abstract}

Keywords: lncRNA; in cis; in trans; CRISPR

\section{Introduction}

The vast majority of the human genomic DNA is transcribed into RNA, of which $2 \%$ encodes proteins, while the remaining $98 \%$ is recognized as noncoding RNA [1]. Long noncoding RNAs (lncRNAs) are defined as transcripts that are longer than 200 nucleotides and are not translated into proteins [2]. LncRNAs have been demonstrated to play roles in chromatin structure and epigenetic remodeling, regulation of pre-mRNA (messenger RNA) splicing, mRNA translation, and RNA metabolism, as well as protein localization, decay, and activity [3]. Mechanistically, lncRNAs regulate gene expression and/or function, either positively or negatively, by interacting with DNA, RNA, and proteins, and have been shown to modulate transcriptional, post-transcriptional, and post-translational processes. At the transcriptional level, lncRNAs act on target genes either in cis (i.e., targeting neighboring genes) or in trans (i.e., targeting distant genes) [2,4].

The field of lncRNAs has exploded in the past decade. Many new lncRNAs have been identified, annotated, and implicated in various physiological and pathological processes, including tumor growth and metastasis. However, ascribing functions to a specific lncRNA has proven considerably more challenging than initially anticipated. Compared with protein-coding genes, our understanding of 
lncRNA functions and mechanisms is much more limited, and many caveats and controversies remain, which could be associated with several characteristics of lncRNAs [5-7]. First, most lncRNAs are expressed at low levels relative to mRNAs and microRNAs, making it difficult to capture and annotate lncRNAs from transcriptomic data [2]. Second, unlike protein-coding genes with readily identifiable open reading frames (ORFs) that facilitate prediction of the structural domains, 2D or 3D structure, and protein-protein interactions, lncRNAs lack significant ORFs, and the lncRNA sequence-function relationship is poorly understood [2]. Third, unlike microRNAs and mRNAs, most lncRNAs have poor sequence conservation among different species, making it difficult to obtain functional information from evolutionary analyses [8]. In addition, many lncRNAs exhibit unique temporal and spatial expression patterns [8].

LncRNA research is more technically challenging than research on protein-coding genes. Whereas small interfering RNA (siRNA) or short hairpin RNA (shRNA) can be used to knock down most protein-coding genes efficiently, the RNAi (RNA interference) approach is relatively less effective for lncRNAs due to their localization and expression [9,10]. Due to recent advances in genome editing, the CRISPR-Cas9 technology has emerged as a potent and versatile tool to manipulate a variety of genomic elements including lncRNAs [11,12]; however, specific constraints exist. For protein-coding genes, it is usually sufficient to use a single guide RNA (gRNA) to target the ORF, because insertion-deletion (indel) mutations can lead to frameshifts and subsequent depletion of the encoded protein [13]. In contrast, lncRNAs have no ORF, and thus, it is highly unlikely that they can be inactivated in this way. Therefore, modifications of the basic CRISPR-Cas9 approach have been developed to target lncRNAs. These include double-gRNA-mediated deletion [11] and transcriptional modulation (activation or inhibition) [14,15]. In this review, we discuss the features of lncRNAs as well as the challenges and strategies in ascribing functions to lncRNAs. In light of the substantial controversies in the field, a framework for the rigorous characterization of lncRNA functions and mechanisms of action needs to be established for lncRNA research.

\section{The Genomics of LncRNA Genes}

Based on the genomic location with respect to the nearest protein-coding gene, lncRNAs can be divided approximately equally into genic and intergenic classes-genic lncRNA genes overlap with a protein-coding gene locus, whereas intergenic lncRNA genes do not [16]. Based on their position and orientation relative to the overlapping protein-coding gene, genic lncRNAs can be divided into sense versus antisense subgroups or intronic versus exonic subgroups.

Classification by genomic location sometimes gives clues on the regulatory mechanism of the lncRNA. For instance, an antisense lncRNA may regulate its sense counterpart through direct sense-antisense pairing. This is exemplified by a lncRNA elevated in Alzheimer's disease, BACE-AS1, which upregulates BACE expression by binding and stabilizing BACE mRNA [17]. Additional antisense lncRNAs, such as Uchl1-AS [18], PDCD4-AS1 [19], and KRT7-AS [20], function similarly to promote mRNA stability or translation through base pairing with their sense counterpart. On the other hand, certain antisense lncRNAs downregulate sense gene expression. For example, the lncRNA GLS-AS inhibits GLS (glutaminase) expression by forming double-stranded RNA with GLS pre-mRNA through a Dicer-dependent RNA interference mechanism, leading to suppression of GLS-mediated metabolism and pancreatic cancer progression [21]. Because of the importance of RNA-RNA interactions in sense-antisense pairing, computational tools, such as MechRNA [22] and IntaRNA 2.0 [23], have been developed to predict the probability of RNA duplex formation based on the calculation of thermodynamic free energy. Moreover, a new sequencing method, named RNA in situ conformation sequencing (RIC-seq) [24], has emerged as an experimental tool to identify RNA-RNA interactions.

In addition to RNA-RNA base pairing, antisense lncRNA genes can also act in cis by interfering with the sense gene transcription, resulting in the inverse correlation between sense and antisense transcripts [25]. This is exemplified by the lncRNA gene Airn, which overlaps with the Igf $2 r$ promoter. This overlap interferes with the recruitment of RNA polymerase II, leading to repression of $I g f 2 r$ gene 
transcription in cis [26]. A recent study revealed another mechanism by which mRNA transcription promotes the transcription of its antisense lncRNA through an R-loop-dependent mechanism [27]. Moreover, antisense lncRNAs can form RNA-DNA complexes to regulate gene expression or act as the scaffold to assemble protein complexes [28-30].

A subgroup of intergenic lncRNAs, called divergent lncRNAs, are transcribed in the opposite direction to nearby protein-coding genes. Divergent lncRNAs and mRNAs are transcribed in a head-to-head fashion, typically less than $1 \mathrm{~kb}$ apart [31,32]. In fact, bidirectional promoters are widely prevalent, and bidirectional genes represent more than $10 \%$ of all human genes [33,34]. In human and murine embryonic stem cells (ESCs), more than $60 \%$ of lncRNA transcripts originate from divergent transcription at promoters of active protein-coding genes (PCGs), and the transcribed lncRNA-mRNA pairs exhibit coordinated changes in transcription during ESC differentiation [35]. Further studies have revealed that many but not all divergent lncRNAs show correlated expression or synergetic effects with their PCG partners, which can be exemplified by $n c R N A-R B 1$ [33] and PANDA [36]. Although the mechanism of this co-regulation is not fully understood, one hypothesis is that the act of transcription itself suppresses negative effects on the promoter, such as the spread of repressive chromatin, permitting steady PCG expression [31]. It has been proposed that divergent transcription may shape the evolution of the genome through the origination of new genes [37].

When investigating IncRNAs, we need to take into account the genomic location and we also should consider the genomic copy-number variation (CNV), especially copy number amplification (CNA)-a common genomic alteration found in human epithelial tumors [38,39]. A valuable tool to study IncRNA genes, the CRISPR-Cas9-mediated genome editing approach, induces double-stranded breaks in DNA by the Cas9 endonuclease in a single guide RNA (sgRNA)-directed sequence-specific manner. This damage can be repaired by nonhomologous end-joining (NHEJ), an error-prone repair method that induces indel mutations [40]. In the case of CNA, there are more sgRNA target sequences, which increases the chance of Cas9-mediated DNA cuts and double-strand break-induced antiproliferative effects [41,42], especially in p53 wild-type cells [43-45]. Another issue is that CNA of essential genes may protect them from complete knockout because Cas9-mediated genome editing is likely to be incomplete and because more copies of the target gene may increase resilience to knockout editing [39]. Because of these issues, CNVs may influence CRISPR screening scores, thus generating false-positive hits. For example, Liu et al. [46] performed a genome-wide CRISPR screen by targeting splice sites of lncRNAs to deplete lncRNA expression. Further analysis of the results from this screen revealed that at least $30 \%$ of the hits were false positives due to either nuclease activity in copy number-amplified regions or overlap with protein-coding genes [42]. The CRISPR interference (CRISPRi) method, which does not induce DNA cuts, could mitigate this issue [15,41,42]. Thus, it is important to consider the copy number of the IncRNA of interest and to choose the proper CRISPR method to target it [47-49].

\section{LncRNA Structure and Its Link to Functions}

RNA adopts various structural elements including the stem-loop, pseudoknot, triplex, and G-quadruplex and is capable of long-range interaction, which contributes to its biological functions [50]. These structural elements can form through intramolecular interactions within the same RNA molecule or intermolecular interactions with other molecules such as other RNA, DNA, and proteins. Identifying RNA motifs, structures, and interactions with binding partners is critical for understanding gene regulation and function [50-53].

For protein-coding genes, the primary sequence of amino acids can be used to predict functional domains and interactions with other proteins, and proteins with similar functions often share common domains. In contrast to proteins, IncRNAs with similar functions often lack a homologous primary sequence, and the knowledge about the function of one lncRNA hardly informs the functions of other lncRNAs [54]. Nevertheless, it is thought that, like proteins, lncRNAs function through "domains" or discrete elements that mediate molecular interactions and subcellular localization [55]. 
One of the mysteries about IncRNAs is the discrepancy between low primary sequence conservation and functionally conserved roles [1]. Hence, significant efforts have been dedicated to the search for conserved structural elements. For instance, a large number of correlated positions in lncRNAs were revealed by multiple alignments, suggesting evolutionary conservation of the secondary structures of IncRNAs $[8,56]$. In addition, many conserved structure elements were found to be enriched in lncRNAs through screening for functional RNA structures conserved between mice and 59 other vertebrates [57]. However, these findings are based on computational predictions. It remains to be seen how many of these predicted conserved structures are real and functionally important in vivo [1].

In addition to computational predictions, experimental support for "domain" prediction and validation for a specific lncRNA is beginning to emerge [58-60]. The structural and biological features of some well-known lncRNAs, such as metastasis associated lung adenocarcinoma transcript 1 (MALAT1) [61-63], nuclear enriched abundant transcript 1 (NEAT1) [62], HOX transcript antisense intergenic RNA (HOTAIR) [64], and lincRNA-p21 [65], have been experimentally characterized. Moreover, methods for probing the RNA "structurome," which couple high-throughput sequencing (HTS) with ribonuclease cleavage or chemical probing, have facilitated the transcriptome-wide mapping of RNA structure [50]. For instance, Fang et al. [66] developed targeted structure-seq, which combines chemical probing of RNA structure in cells with target-specific HTS. By enriching for signals from the RNA of interest, targeted structure-seq achieved high coverage of the full-length Xist (X-inactive specific transcript) lncRNA. It should be noted that HTS-based RNA structure profiling technologies rely heavily on the development of robust computational methods. Significant challenges in these methods, such as the need to improve the accuracy, signal-to-noise ratio, and sequencing depth, remain to be overcome.

Recent studies have demonstrated the use of specific elements to predict lncRNA localization and function. Carlevaro-Fita et al. [55] reported that a subset of transposable elements (TEs), otherwise known as repeat insertion domains of lncRNA (RIDLs), undergo evolutionary selection and can drive nuclear enrichment of lncRNAs. TEs act as functional lncRNA domains through two possible mechanisms: (1) TEs are recognized by the cellular transport pathway; (2) TEs destabilize transcripts, causing a concentration gradient from the nucleus to the cytoplasm [55]. Other elements, such as Alu elements and C-rich motifs, both of which interact with the nuclear RNA-binding protein HNRNPK, can increase the nuclear accumulation of lncRNAs in a conserved manner [67]. Thus, while the precise molecular mechanisms remain to be validated, elements like TEs, Alu elements, and C-rich motifs are valuable for predicting lncRNA localization and function.

Another way of predicting lncRNA functions is k-mer-based classification, which is a sequence comparison method designed to deconstruct linear sequence relationships in lncRNAs and assess similarity based on the abundance of short motifs named k-mers (" $k$ " here specifies the length of the motif, varying from three to eight) [54]. K-mer profiles are found to correlate with the protein binding and subcellular localization of lncRNAs. Interestingly, evolutionarily unrelated lncRNAs could exert similar functions through different spatial arrangements of related sequence motifs. Altogether, k-mer-based classification is a useful approach to predict sequence-function relationships in IncRNAs [54].

In Table 1, we summarize the lncRNA motifs and elements that have been implicated in regulating lncRNA functions. The regulations are categorized into three subgroups: regulation of lncRNA stability, regulation of lncRNA localization, and regulation of lncRNA interactions with other molecules. 
Table 1. List of long noncoding RNA (lncRNA) motifs and elements.

\begin{tabular}{|c|c|c|c|}
\hline Motifs and Elements & LncRNAs & Functions or Characteristics & References \\
\hline \multicolumn{4}{|l|}{ Regulation of stability } \\
\hline $\begin{array}{l}\text { Highly conserved triple helical } \\
\text { structure at the } 3^{\prime} \text { end }\end{array}$ & $\begin{array}{l}\text { MALAT1 } \\
\text { NEAT1_2 }\end{array}$ & $\begin{array}{l}\text { Critical for protecting the } 3^{\prime} \text { end of MALAT1 } \\
\text { from } 3^{\prime}-5^{\prime} \text { exonucleases; promoting lncRNA } \\
\text { stability }\end{array}$ & {$[63,68,69]$} \\
\hline Alu element & IncRNA_AF087999 & $\begin{array}{l}\text { Base-pairing between the Alu element of a } \\
\text { lncRNA and the Alu element of the } 3^{\prime} \text { UTR of } \\
\text { mRNA can create a STAU1-binding site, which } \\
\text { regulates mRNA decay }\end{array}$ & [70] \\
\hline \multicolumn{4}{|l|}{ Regulation of localization } \\
\hline AGCCC motif & BORG & $\begin{array}{c}\text { Critical for nuclear localization of BORG. The } \\
\text { binding partner of the motif and the specific } \\
\text { mechanism are unknown }\end{array}$ & [60] \\
\hline $\begin{array}{l}\text { 156-bp repeating RNA domain } \\
\text { (RRD) }\end{array}$ & FIRRE & $\begin{array}{l}\text { Mediates the interaction with hnRNPU to } \\
\text { regulate FIRRE nuclear localization }\end{array}$ & [71] \\
\hline $\begin{array}{l}\text { SINE-derived nuclear RNA } \\
\text { localization element }\end{array}$ & $J P X, P V T 1$ & $\begin{array}{l}\text { Binds the RNA-binding protein HNRNPK to } \\
\text { promote nuclear localization of the lncRNA }\end{array}$ & [67] \\
\hline C-rich motif & Multiple lncRNAs & $\begin{array}{l}\text { Enriched in nuclear transcripts } \\
\text { U1 snRNA binds extensively to MALAT1 }\end{array}$ & {$[67,72]$} \\
\hline U1 snRNA binding site & MALAT1 & $\begin{array}{l}\text { IncRNA via U1 snRNP recognition sites to } \\
\text { retain MALAT1 on the chromatin }\end{array}$ & [73] \\
\hline $\begin{array}{l}\text { Transposable element (TE), } \\
\text { otherwise known as RIDL } \\
\text { (repeat insertion domain of } \\
\text { lncRNA) }\end{array}$ & $\begin{array}{l}\text { RP11-5407, } \\
\text { LINC00173, } \\
\text { RP4806M20.4 }\end{array}$ & $\begin{array}{c}\text { Certain TEs/RIDLs, such as L2b, MIRb, and } \\
\text { MIRc, promote the nuclear enrichment of } \\
\text { lncRNAs, while GC-rich RIDL elements } \\
\text { correlate with cytoplasmic localization of } \\
\text { lncRNAs }\end{array}$ & {$[55,74]$} \\
\hline $\begin{array}{l}\text { Short interspersed nuclear } \\
\text { element (SINE) }\end{array}$ & MALAT1 & $\begin{array}{l}\text { SINE deletion leads to the export of MALAT1 to } \\
\text { the cytoplasm }\end{array}$ & [59] \\
\hline \multicolumn{4}{|l|}{ Regulation of interaction } \\
\hline A-repeat element & XIST & $\begin{array}{l}\text { Interacts with Spen protein to mediate } \\
\text { transcriptional silencing; critical for X } \\
\text { chromosome inactivation }\end{array}$ & [75] \\
\hline $\begin{array}{l}\text { Conserved short sequence } \\
\text { motif }\end{array}$ & LINC-PINT & $\begin{array}{l}\text { Mediates the interaction with PRC2 and } \\
\text { contributes to PRC2-dependent silencing }\end{array}$ & [58] \\
\hline PUMILIO response element & NORAD & $\begin{array}{l}\text { Competes against the target mRNAs of } \\
\text { PUMILIO proteins }\end{array}$ & {$[76,77]$} \\
\hline $\begin{array}{l}\text { Conserved androgen receptor } \\
\text { (AR)-binding motif }\end{array}$ & $\begin{array}{l}\text { SLNCR1, } \\
\text { HOTAIR, } \\
\text { PCGEM1 }\end{array}$ & $\begin{array}{l}\text { Required for the AR-IncRNA association and } \\
\text { regulates the transcriptional activity of AR }\end{array}$ & [78-80] \\
\hline
\end{tabular}

MALAT1: Metastasis Associated Lung Adenocarcinoma Transcript 1. NEAT1: Nuclear Enriched Abundant Transcript 1. UTR: untranslated region. STAU1: Staufen Double-Stranded RNA Binding Protein 1. BORG: BMP/OP-Responsive Gene. FIRRE: Functional Intergenic Repeating RNA Element. JPX: Just Proximal to XIST. PVT1: Plasmacytoma Variant Translocation 1. hnRNPU: Heterogeneous Nuclear Ribonucleoprotein U. HNRNPK: Heterogeneous Nuclear Ribonucleoprotein K. snRNP: small nuclear ribonucleoprotein. TE: transposable element. RIDL: repeat insertion domain of lncRNA. SINE: short interspersed nuclear element. XIST: HOX Transcript Antisense Intergenic RNA. LINC-PINT: Long Intergenic Non-protein Coding RNA, p53 Induced Transcript. NORAD: Non-coding RNA Activated by DNA Damage. SLNCR1: SRA-Like Non-Coding RNA 1. HOTAIR: HOX Transcript Antisense RNA. PCGEM1: Prostate Cancer Gene Expression Marker 1. AR: androgen receptor.

\section{The Subcellular Localization and Stability of LncRNAs}

Unlike mRNAs, IncRNAs are more abundant in the nucleus than in the cytoplasm [7]. Previous reviews have summarized the relationship between the subcellular location and function of lncRNAs in detail [81,82]. Here we mainly discuss how to predict a lncRNA's subcellular distribution through its primary manifestations such as its sequence, and how to determine lncRNA's localization experimentally.

The structure of lncRNA correlates with the subcellular localization. Recently developed HTS-based methods have provided rich information through the analysis of sequence elements such as TEs, Alu elements, and C-rich motifs, as discussed above. A limitation is that the element analysis of the primary sequence may not be fully informative, since the 2D or 3D structure of IncRNA could influence the localization. Methods to predict the localization of lncRNAs by analyzing high-dimension structures in a high-throughput way are still lacking. 
The lncRNA localization can be visualized by staining methods, such as fluorescent in situ hybridization (FISH). This method is based on tracking the target RNA with multiple short DNA probes, which are complementary to the target and are conjugated with a fluorescent dye [83]. For imaging intracellular localization of single RNA transcripts in fixed cells or tissues, FISH is still regarded as the gold-standard approach [84,85]. For live-cell imaging of the RNA of interest, stem-loop labeling and fluorescence protein tagging by the MS2-MCP system are useful $[86,87]$. However, the insertion of dozens of MS2 aptamers into specific IncRNA gene loci makes widespread application of this method difficult, and a common concern is whether such insertions affect RNA structure, dynamics, expression, and function. Recently, CRISPR technology has provided a new approach to determine RNA localization in live cells. The nuclear-localized RNA-targeting Cas9 (RCas9) can be used to visualize highly abundant mRNAs in live cells $[88,89]$, but it is not suitable for most lncRNAs, which are not abundantly expressed. On the other hand, a novel CRISPR-Cas13 system showed feasibility in imaging lncRNAs in real-time with high specificity and sensitivity [82]. Unlike Cas9, Cas13 specifically binds to RNA, not double-stranded DNA. Recent engineering of CRISPR-Cas13 has enabled precise RNA targeting and editing in mammalian cells [90]. Yang et al. [91] compared different bacteria and identified dPspCas13b from Prevotella sp. P5-125 as the most efficient one; they showed that an optimized dCas13 system could label NEAT1, SatIII, MUC4, and GCN4 RNAs and that combining dCas13 with MS2-MCP or Cas9 achieved dual-color imaging of RNAs or simultaneous visualization of RNA and genomic DNA in living cells [91]. Widespread use of this technology still awaits general guidelines for designing efficient gRNAs targeting a lncRNA of interest. For effective gRNA targeting, the structure and conformation of the targeted lncRNA should be considered.

In addition to FISH and CRISPR, novel high-throughput methods have been developed to detect lncRNA distribution. For instance, Yin et al. [73] used a random, mutagenesis-coupled, high-throughput method called RNA elements for subcellular localization by sequencing (mutREL-seq) to identify an RNA motif that recognizes the U1 small nuclear ribonucleoprotein (snRNP) and is critical for the localization of RNAs to chromatin. Moreover, predictive models, based on systematic analyses of deep sequencing results including expression levels, splicing, gene architecture, chromatin marks, and sequence elements, can be an alternative way of predicting lncRNA localization [92]. Notably, many lncRNAs have both nuclear and cytoplasmic fractions, and they have different functions and mechanisms of action in different subcellular compartments. For example, when localized in the cytoplasm, the lncRNA MEG3 interacts with PTBP1 (polypyrimidine tract binding protein 1) to promote mRNA decay [93]; when in the nucleus, MEG3 forms RNA-DNA triplex structures to regulate genes in the TGF- $\beta$ pathway [94].

In addition to subcellular localization, IncRNA stability should also be considered when investigating lncRNA functions. In systematic surveys, Clark et al. [95] used a custom noncoding RNA array to analyze the half-lives of approximately 800 lncRNAs and 12,000 mRNAs in the mouse Neuro-2a cell line, and Tani et al. [96] developed a 5'-bromo-uridine immunoprecipitation chase-deep sequencing (BRIC-seq) method, which involves pulse-labeling of endogenous RNAs with 5-bromo-uridine and measuring the decrease in RNA levels over time through sequencing. These studies revealed that lncRNA stability varies over a wide range, and the half-life of a significant set of short-lived lncRNAs is regulated by external stimuli.

Notably, lncRNA stability correlates with localization and could to some degree inform the regulatory function [96]. Tracking the subcellular localization of lncRNAs revealed widespread trafficking to different cellular locations, with nuclear lncRNAs more likely to be unstable $[95,97]$. In fact, nuclear transcripts are generally less stable [8,98]. The fast turnover of short-lived nuclear IncRNAs renders these transcripts less likely to leave the chromatin through a U1 snRNP-mediated mechanism $[73,99]$. The coupling between the chromatin association and instability of lncRNAs may contribute to the in-cis regulatory function of lncRNAs. Indeed, most short-lived lncRNA transcripts spread locally within their neighborhoods, whereas a few stable and abundant lncRNAs, such as MALAT1, exist long enough to be trans-targeted to other sites. For stable lncRNAs, persistent binding 
with U1 snRNP may drive lncRNA mobilization to distinct nuclear compartments (such as nuclear speckles) or distant genomic sites (in the case of MALAT1) [73].

\section{Evolutionary Conservation and Tissue Specificity of LncRNAs}

High-throughput sequencing (HTS) analysis across species has revealed that certain lncRNA elements, such as lncRNA gene promoters, have a similar level of conversation to mRNA promoters in humans and mice $[8,100]$. Splicing motifs are also evolutionarily retained in many lncRNAs across species [101]. LncRNA exons are much more conserved than are neutrally evolving ancestral repeat sequences, albeit at much lower levels than protein-coding genes [8].

LncRNA expression is often species-specific. An across-mammalian-genomes analysis showed that $30 \%$ of lncRNA transcripts $(n=4546)$ are primate-specific (human, chimp, orangutan, macaque, and marmoset) [8]. A total of $0.7 \%$ of lncRNAs are specific to the human lineage, and $\sim 1 \%$ of $\operatorname{lncRNAs}$ are expressed in all of the 18 species analyzed. Aside from species specificity, lncRNA expression is often tissue type- and cell type-specific- $11 \%$ of $\ln$ RNAs (versus $65 \%$ of mRNAs) are detected in all human tissues; $21 \%$ of lncRNAs are not detected in any human tissue, and $11 \%$ are detected only in a single tissue type [8]. Tissue-type specificity analysis showed that lncRNAs are particularly more specific in the brain, testis, and stem cells [102-105]. LncRNA expression is also context- and time-dependent. Specific lncRNAs are expressed at different stages of immune cell differentiation and drive the process [4]. For instance, $L n c-D C$ is responsible for the differentiation from myeloid progenitor cells or monocytes into dendritic cells [106]. Also, some lncRNAs have been shown to regulate the activation or inactivation of immune cells, e.g., Nest [107] promotes T cell activation, whereas NRON [108,109] restricts excess activation.

Comparative analysis requires a set of genes that can be compared as well as the algorithms for matching and similarity evaluation. This is challenging for lncRNAs, because (1) lncRNAs in species other than human and mouse are poorly annotated. (2) LncRNAs lack long regions with high sequence conservation needed for comparison. A lncRNA conserved between human and mouse typically has only $20 \%$ inter-species homology, and this drops to $5 \%$ when comparing human and fish [110]. Moreover, even for lncRNAs expressed in the same tissue among species, the conservation rate is still low. Comparison of IncRNA expression in the livers of mice, rats, and humans revealed that only $60 \%$ and $27 \%$ of lncRNAs expressed in mice have homologs expressed in rats and humans, respectively, suggesting that lncRNAs are rapidly evolving in the same tissue across species [111]. (3) Experimental evidence for lncRNAs acting through specific structures is limited; notable exceptions are the Rep A repeat in XIST [112,113] and the triple-helix that stabilizes the $3^{\prime}$ ends of MALAT1 and NEAT1_2 [63,68,114]. Overall, lncRNAs are less conserved and more species-specific than are protein-coding genes.

It should be noted that conservation can be defined at several levels based on the sequence, structure, and subcellular location. A recent review suggested four classifications of lncRNAs according to these characteristics, specifically Class I (conserved exonic structure), Class II (conserved sequence), Class III (positionally conserved), and Class IV (not conserved) [115]. Class I lncRNAs, whose exon-intron structures and sequences are conserved among species, constitute a minority of conserved lncRNAs, including MALAT1 and NEAT1. LncRNAs in this class tend to have more conserved functionality and less tissue specificity among different species; they are highly expressed relative to other classes and often act in trans. Class III lncRNA genes, which are conserved in the act of transcription of the specific region without sequence or structure conservation, are more likely to function in cis through the act of transcription rather than through the mature RNA transcript [115].

Long non-coding RNAs can also be functionally conserved through the following manifestations [115]: (1) loss of homologous lncRNAs results in the same phenotype; (2) homologous lncRNAs function through the conserved mechanism; (3) target genes regulated by lncRNAs are the same; and (4) the loss of function in one species can be rescued by exogenous expression of the homolog from a different species. Experimentally validated examples include XIST, which has a key 
role in $\mathrm{X}$ inactivation in both humans and mice [116], and NEAT1, which is essential for paraspeckle formation across species $[117,118]$. On the other hand, do homologous lncRNAs across species always have the same function? Through systematic high-throughput analysis of sequence and positionally conserved lncRNAs across species, Guo et al. [119] discovered the distinct subcellular localization and function of the lncRNA FAST (FOXD3 anti-sense transcript 1) in human and mouse embryonic stem cells (ESCs). In human ESCs, FAST is mainly expressed in the cytoplasm, where it blocks the interaction of the ubiquitin ligase $\beta$-TrCP (transducin repeats-containing protein) with phosphorylated $\beta$-catenin, leading to the prevention of $\beta$-catenin degradation, activation of WNT signaling, and maintenance of pluripotency. In contrast, mouse Fast is nuclear retained in ESCs, and its processing is inhibited by the splicing factor PPIE (peptidylprolyl isomerase E), which is abundantly expressed in mouse ESCs but not in human ESCs [119]. As another example, the lncRNA HOTAIR has been reported to have different functions in humans and mice: whereas HOTAIR regulates the expression of the HOXD cluster in primary human fibroblasts [120], Hoxd expression is not affected in mice with deletion of the Hoxc cluster encompassing Hotair [121]. Furthermore, different groups have reported contradictory results in phenotypes and Hoxd expression in Hotair-knockout mice [122,123], and this discrepancy remains to be resolved [124]. In sum, when studying a specific lncRNA, it is important to take into account the conservation among species and the lncRNA localization and expression patterns among tissue types.

For investigating cancer-implicated lncRNAs, it is important to consider cancer-type specificity [125,126]. Yan et al. [125] performed a comprehensive analysis of 5037 tumor samples across 13 cancer types from The Cancer Genome Atlas and found that compared with protein-coding genes, the expression and dysregulation of IncRNAs are highly cancer type-specific and are characterized by tumor tissue type-specific IncRNA alterations such as somatic copy number alterations, promoter hypermethylation, and cancer-associated single-nucleotide polymorphisms (SNPs). Some of the lncRNAs that are deregulated in cancer have been functionally characterized. For instance, Hu et al. [127] combined copy-number alteration analysis and loss-of-function screening to identify an oncogenic lncRNA, FAL1 (focally amplified lncRNA on chromosome 1), that is amplified in ovarian cancer. Interestingly, FAL1 lncRNA interacts with the epigenetic regulator BMI1 (B cell-specific Moloney murine leukemia virus integration site 1) to repress its target genes including CDKN1A (encoding p21) [127]. SNPs associated with cancer risk may involve cancer-driver lncRNAs, as exemplified by CCAT2 (colon cancer associated transcript 2), a lncRNA that encompasses the rs6983267 SNP and is overexpressed in microsatellite-stable colorectal cancer [128]. The SNP rs6983267 has two allelic forms containing either $\mathrm{T}$ or $\mathrm{G}$, with the $\mathrm{G}$ allele associated with a higher risk for colorectal cancer than the T allele [128]. Altogether, genomic and pan-cancer analyses of lncRNAs have provided valuable information about cancer-driver lncRNAs and their potential use in cancer classification, diagnosis, prognosis, risk assessment, and treatment [125,129-132].

\section{LncRNA Functions: In Cis versus In Trans}

The regulatory functions of lncRNAs can be classified broadly as in-cis regulation and in-trans regulation [2] (Figure 1). Notably, some cis-acting lncRNA genes do not act in a sequence-specific manner; instead, the act of transcription or the DNA element within the lncRNA gene locus is more likely to be the root of the regulatory activity than is the lncRNA transcript [133]. Thus, cis-acting lncRNAs have at least three possible mechanisms of action [2] - (1) the lncRNA molecule regulates the transcription of its adjacent genes by recruiting proteins or molecular complexes to the locus or by modulating their activities; (2) the process of transcription or splicing of the lncRNA affects its neighboring gene expression in a sequence-independent manner; and (3) the DNA elements within the IncRNA gene act as regulatory sequences for nearby genes. 
A

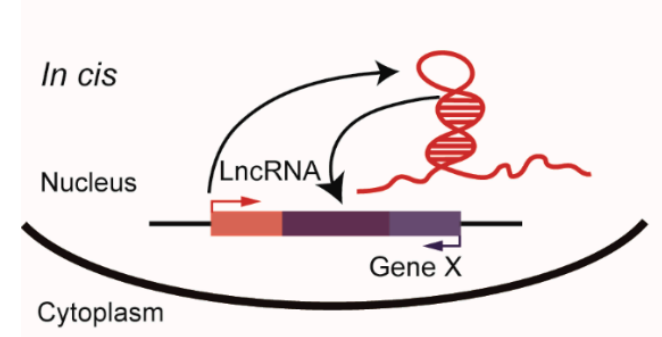

C

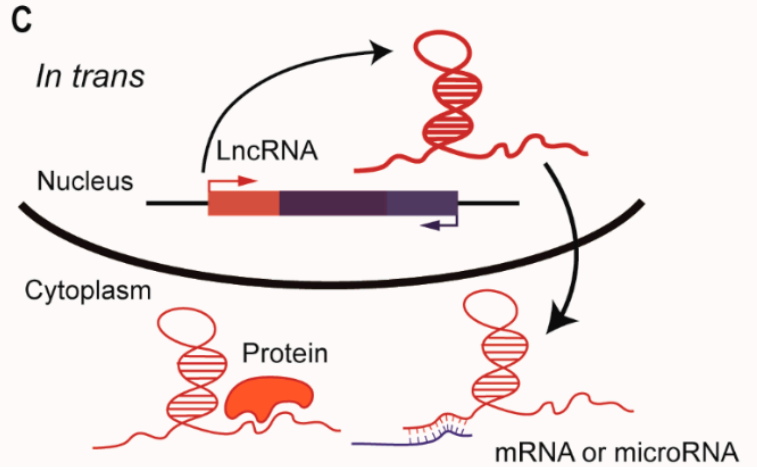

B

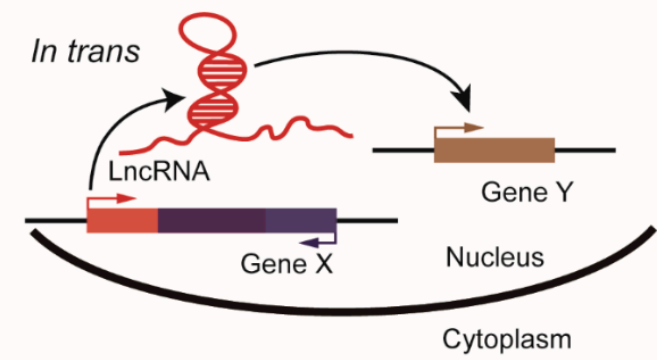

asm 
suppressors and the antigen peptide-loading complex [136]. Some lncRNAs can form a feedback loop with their target to promote oncogenic signaling. For example, PVT1 (plasmacytoma variant translocation 1) is a well-known lncRNA that is amplified or overexpressed in cancer. Both MYC and PVT1 are located on chromosome 8q24, a region amplified in cancer. Upon phosphorylation on threonine 58 (Thr58), MYC protein is destabilized and degraded by proteasomes. The lncRNA PVT1 promotes MYC stability by inhibiting its Thr58 phosphorylation. MYC protein, in turn, translocates into the nucleus and interacts with the PVT1 promoter to activate its transcription [137-139].

Loss-of-function studies of trans-acting lncRNAs should include genetic rescue experiments, in which the lncRNA is re-expressed from an independent transgene, to distinguish RNA-specific effects from those arising from manipulation of the underlying genomic DNA or other non-specific effects. MALAT1 is among the most conserved lncRNAs and is highly abundant in normal tissues [140]. Recently, Kim et al. [134] used a transcriptional terminator insertion strategy [141] and found that targeted inactivation of the MALAT1 gene in a transgenic mouse model of breast cancer, without altering the expression of its adjacent genes, promoted lung metastasis; importantly, this phenotype was reversed by genetic add-back of MALAT1. Similarly, double gRNA- and CRISPR-Cas9-mediated focal deletion of MALAT1 in human breast cancer cells, which did not affect MALAT1's neighboring gene expression, induced the ability of these cells to metastasize to the lung, which could be reversed by re-expression of MALAT1 [134]. Conversely, overexpression of MALAT1 suppressed breast cancer lung metastasis in transgenic, xenograft, and syngeneic models. Mechanistically, Kim et al. [134] found that MALAT1 lncRNA binds, sequesters, and inactivates the pro-metastatic transcription factor TEAD (TEA domain), preventing TEAD from associating with its co-activator YAP (Yes-associated protein) and target gene promoters. Unlike previous MALAT1 studies that used large genomic deletions or antisense oligonucleotides (ASOs) without rescue experiments [142], Kim et al. [134] used targeted insertional inactivation and focal deletion approaches, both with genetic rescue experiments to rule out non-specific effects [143]. The findings by Kim et al. [134] demonstrate that MALAT1 is a metastasis-suppressing lncRNA rather than a metastasis promoter in breast cancer, raising caution about targeting MALAT1 as an antimetastatic strategy. Furthermore, the work by Kim et al. [134] suggests that the previously observed upregulation of Malat1's 12 adjacent genes upon MALAT1 gene deletion [142] was not due to the loss of MALAT1 RNA.

When assessing in-cis versus in-trans regulation, it is important to take into account the copy number of the IncRNA. A key question is whether the lncRNA of interest is abundant enough to exert the proposed effect, especially when its target is highly expressed. Thus, when considering the stoichiometric interaction, it is imperative to know the copy numbers of the lncRNA and its targets to establish the plausibility of the regulatory mechanism. For instance, the lncRNA NORAD has been identified as a molecular decoy of the RNA-binding proteins PUM1 and PUM2 [76]. PUM proteins bind the $3^{\prime}$ UTR of mRNAs to regulate target mRNA translation and decay. PUM-binding RNAs contain a conserved sequence, UGUANAUA, termed the PUMILIO response element (PRE) [144]. NORAD is an abundantly expressed lncRNA and each NORAD transcript has 15 PRE sequences. In cells, this lncRNA is sufficient to occupy PUM1 and PUM2 proteins, and the stoichiometric interaction can explain how NORAD competes against PUM proteins' target mRNAs and inhibits their ability to bind other RNAs [76,77]. Another example is lincRNA-p21. Initially, RNAi experiments suggested that $\operatorname{lin} C R N A-p 21$ represses gene transcription globally in trans [145]; however, a knockout mouse model, generated by focal deletion of the promoter and the first exon, revealed a role for lincRNA- $p 21$ in activating p21 expression in cis [146]. In light of the short half-life $(<2 \mathrm{~h})$ and low copy number (8 copies per cell) of lincRNA-p21 [146,147], it is unlikely that this lncRNA has a global in trans effect on the genome.

\section{Strategies for Studying LncRNA Functions}

Considering the features of lncRNAs and the challenges in lncRNA research mentioned above, we recommend a framework for the characterization of lncRNAs (Figure 2), with specific examples. 
First, we can obtain the annotation of the specific lncRNA through sequence analysis and rule out the protein-coding potential by using algorithms such as PhyloCSF [148]. Next, we can evaluate the likely regulatory mechanism of the lncRNA, in cis or in trans, by analyzing the genomic location, copy number, domain structure, subcellular localization, stability, evolution, and expression pattern as mentioned above. Then, we can examine the expression levels of adjacent genes upon lncRNA depletion, which could be achieved by RNAi, ASOs, and CRISPR-based methods including promoter deletion, entire locus deletion, insertional inactivation (by knocking in a transcriptional terminator), or CRISPRi. The mechanisms, outcomes, and limitations of these methods are summarized in Figure 3. It should be noted that the CRISPR approach has potential drawbacks $[42,149,150]$ and that CRISPR itself may affect local gene expression. For lncRNA genes with copy number amplification, CRISPR-mediated locus deletion might not be suitable because of the increased chances of Cas9-induced DNA cuts and double-strand breaks [42]. For divergent lncRNAs such as Uph [151] and BISPR [152], CRISPR-mediated promoter deletion should be avoided because of the influence on gene transcription in the opposite direction.

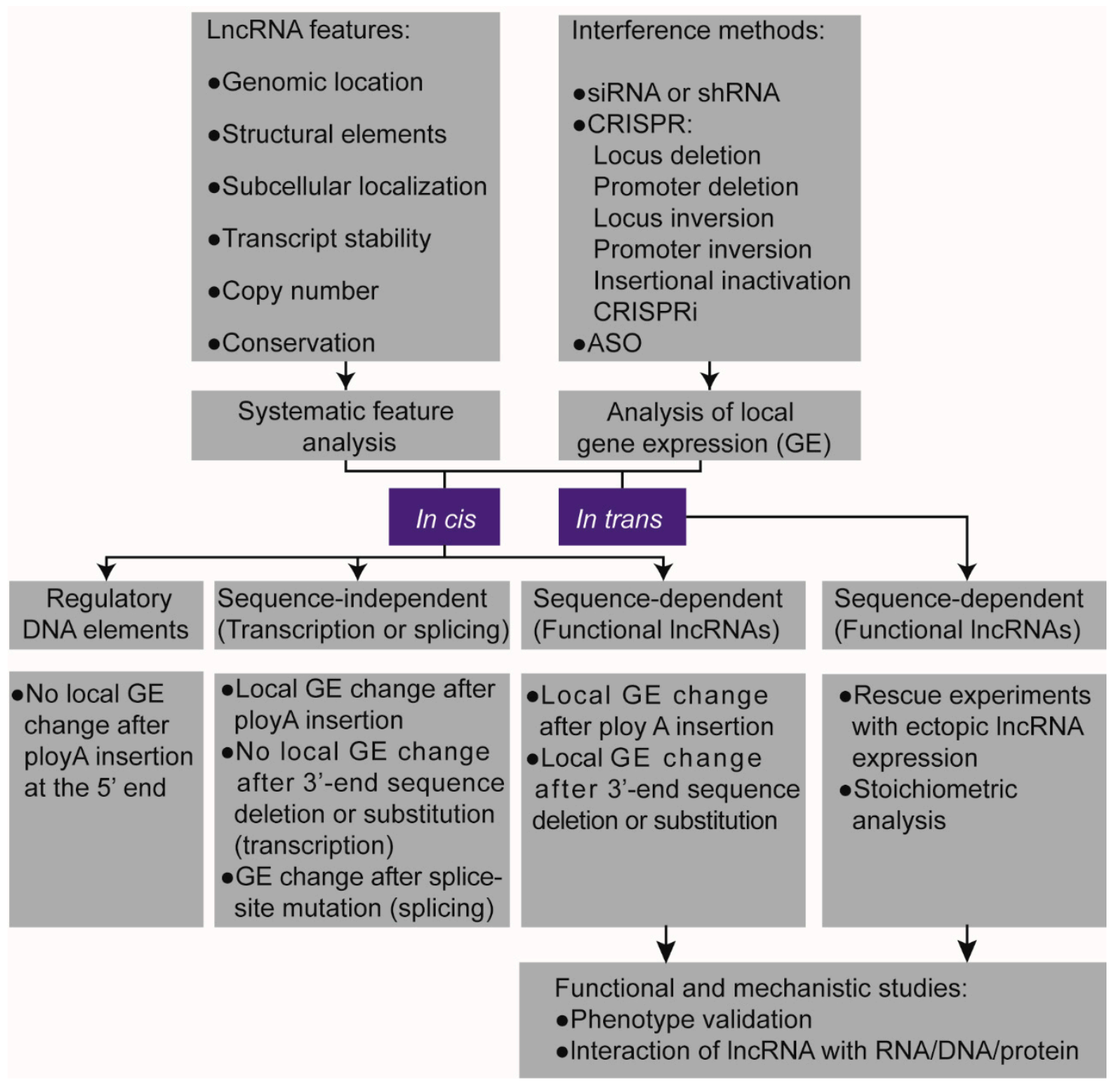

Figure 2. Framework for the functional characterization of lncRNAs. CRISPR: Clustered regularly interspaced short palindromic repeats. ASO: antisense oligonucleotide, lncRNA: long non-coding RNA, siRNA: small interfering RNA, shRNA: short hairpin RNA. 


\begin{tabular}{|c|c|c|c|c|}
\hline Methods & Mechanisms & Outcomes & $\begin{array}{l}\text { Stable } \\
\text { effects }\end{array}$ & Limitations \\
\hline \multicolumn{5}{|l|}{ WT IncRNA locus } \\
\hline $\begin{array}{r}\text { Deletion } \\
\text { Locus deletion }\end{array}$ & & $\begin{array}{l}\text { LncRNA } \\
\text { knockout }\end{array}$ & Yes & $\begin{array}{l}\text { Disruption of the genomic locus; } \\
\text { may delete regulatory elements }\end{array}$ \\
\hline Promoter deletion & & $\begin{array}{l}\text { LncRNA } \\
\text { knockout }\end{array}$ & Yes & $\begin{array}{l}\text { Alteration of the regulatory DNA } \\
\text { sequcence }\end{array}$ \\
\hline $\begin{array}{l}\text { Inactivation } \\
\text { Insertional inactivation }\end{array}$ & & $\begin{array}{l}\text { LncRNA } \\
\text { knockout or } \\
\text { knockdown }\end{array}$ & Yes & $\begin{array}{l}\text { Efficiency depends on the locus; } \\
\text { may disrupt long-range genomic } \\
\text { interaction }\end{array}$ \\
\hline $\begin{array}{r}\text { Inversion } \\
\text { LncRNA inversion }\end{array}$ & & $\begin{array}{l}\text { Non-functional } \\
\text { transcript }\end{array}$ & Yes & Disruption of the genomic locus \\
\hline Promoter inversion & & $\begin{array}{l}\text { LncRNA } \\
\text { knockout }\end{array}$ & Yes & $\begin{array}{l}\text { Alteration of the regulatory DNA } \\
\text { sequcence }\end{array}$ \\
\hline CRISPRi & & $\begin{array}{l}\text { LncRNA } \\
\text { knockdown }\end{array}$ & Yes & Efficiency depends on the locus \\
\hline ASO & & $\begin{array}{l}\text { Nuclear IncRNA } \\
\text { knockdown }\end{array}$ & No & Off-target effects \\
\hline RNAi & - & $\begin{array}{l}\text { Cytoplasmic IncRNA } \\
\text { knockdown }\end{array}$ & No & Off-target effects \\
\hline
\end{tabular}

Figure 3. Loss-of-function approaches for investigating lncRNAs. Dark red rectangles: lncRNA exons. Dark blue rectangles: neighboring protein-coding genes. Brown ovals: transcriptional factors. Arrows: the direction of transcription. Black rectangle: transcriptional terminator (Term). Antisense oligonucleotides (ASOs) are illustrated by a complementary sequence to the nascent RNA transcript, which decreases lncRNA expression by triggering RNase H (yellow oval)-mediated cleavage. CRISPRi employs sgRNA-mediated targeting of dCas9 (light blue oval) to the region near the transcriptional start site to repress gene expression, and the repression is enhanced by fusing Cas 9 with a repressor, such as the Kruppel-associated box (KRAB) domain (green rectangle). RNAi is triggered by short RNA species that bind to argonaute protein (Ago), which forms a complex to recognize complementary mRNA and lncRNA molecules and induce their degradation.

For cis-acting lncRNA genes that function in an RNA-independent manner, loss-of-function phenotypes would be seen after deletion of the promoter or specific regulatory DNA elements in the lncRNA gene locus, but not upon the deletion of downstream exons and introns. This is exemplified by linc1319 (or Blustr), which regulates the expression of its neighboring gene Sfmbt2 in cis [132]. Promoter deletion or insertion of polyA signals that prematurely terminates transcription, or mutation of the first $5^{\prime}$ splice site of Blustr, resulted in significant downregulation of Sfmbt2. However, sequential deletions of downstream exons and introns of the Blustr gene did not affect Sfmbt2 expression, suggesting that its cis-activating effect is not dependent on its RNA transcript [132].

For trans-acting lncRNAs, ASOs have been used to interfere with lncRNA expression in addition to CRISPR-based gene-editing methods. ASOs include gapmers, duplex RNAs, and locked nucleic acids [52]. The RNA-DNA duplex triggers RNase-H-dependent cleavage of transcripts, leading to lncRNA knockdown [153]. This mechanism occurs mainly in the nucleus, making it useful for targeting nuclear lncRNAs that are not amenable to siRNA- or shRNA-mediated silencing. The use of ASOs to knock down lncRNAs has been tested in cancer models, with reported inhibitory effects on tumor growth and progression [154]. However, in addition to the intended target RNA, ASOs may also bind to partially complementary target sites, leading to degradation of unintended RNAs [153]. Moreover, two recent back-to-back studies, from the Mendell group and Ionis Pharmaceuticals, respectively, reported that ASOs cleave nascent RNAs and serve as natural triggers for transcriptional termination 
mediated by the exonuclease XRN2 [155,156]. A strategy to overcome this side effect is to design ASOs that target the $3^{\prime}$ end of the lncRNA transcript, which allows knockdown of the lncRNA while minimizing the effect on Pol II-dependent transcription [155].

Notably, certain IncRNAs have opposing functions to their genomic DNA. Yin et al. [157] reported opposite effects from the lncRNA Haunt gene deletion and insertional inactivation: whereas insertional inactivation of Haunt with minimal disruption of its genomic locus led to upregulation of HOXA genes, large genomic deletion of the Haunt locus attenuated HOXA expression. Mechanistically, the Haunt gene locus contains enhancers of HOXA, whereas Haunt RNA acts to downregulate HOXA expression. These findings indicate that the Haunt gene deletion effect can be attributed to the loss of the genomic DNA, which dominated the effect of Haunt RNA loss.

In addition to Haunt and lincRNA-p21 discussed above, accumulating evidence has demonstrated substantially different or opposite phenotypes resulting from different strategies for inactivating the same lncRNA. In mice, genetic deletion of the lncRNA gene Fendrr resulted in defects in the lung and gastrointestinal tract [158], whereas transcriptional terminator insertion led to defects in the heart and body wall, which could be rescued by a Fendrr transgene [159]. Moreover, RNAi experiments suggested that the lncRNA Evf2 is important for activating Dlx5/6 expression [160], but transcriptional terminator insertion in mice showed the opposite effect [161], which could be rescued by an Evf2 transgene [162]. A recent study characterized the off-target effects of three common loss-of-function methods at the whole-transcriptome level [163]. All three methods, RNAi, ASOs, and CRISPRi, had off-target effects in gene expression. Intriguingly, the various methods each yielded distinct sets of differentially expressed genes as well as different cellular phenotypes. These discrepancies have been observed for the lncRNA MALAT1, the protein-coding gene Ch-TOG/CKAP5, and a previously uncharacterized lncRNA [163]. Collectively, these findings support the existence of method-specific off-target effects and underscore the importance of alleviating such effects.

\section{Conclusions}

Despite the explosion of publications on IncRNAs in recent years, many caveats and controversies remain in the field. Here, we have discussed the current challenges and experimental strategies in ascribing functions to lncRNAs. Loss-of-function (LOF) approaches, such as RNAi, ASOs, and CRISPR-based genome editing, have proven valuable for studying the biological functions of lncRNAs in normal physiology and cancer. As elaborated above, each method has its limitations. A major concern is non-specific targeting, which has been shown to account for false results in anticancer target identification and characterization. Such off-target effects can be mitigated by (1) analyzing the features of the lncRNA of interest to assess the likelihood of in-cis versus in-trans regulation; (2) using multiple carefully controlled LOF approaches to determine if the LOF effects (including the effect on adjacent gene expression) are consistent; (3) complementing LOF approaches with gain-of-function approaches; and (4) performing genetic rescue experiments.

Author Contributions: Y.Z. and L.M. wrote the manuscript. H.T. made the figures. F.Y., S.Y., and Y.S. provided intellectual input and edited the manuscript. All authors have read and agreed to the published version of the manuscript.

Funding: Y.S. is supported by MD Anderson's Cancer Center Support Grant from the US National Cancer Institute (NCI P30CA016672). L.M. is supported by NCI grants R01CA166051 and R01CA181029 and a Cancer Prevention \& Research Institute of Texas grant RP190029.

Acknowledgments: We thank Christine Wogan for the critical reading of the manuscript.

Conflicts of Interest: The authors declare no conflict of interest.

\section{References}

1. Qian, X.; Zhao, J.; Yeung, P.Y.; Zhang, Q.C.; Kwok, C.K. Revealing lncRNA Structures and Interactions by Sequencing-Based Approaches. Trends Biochem. Sci. 2019, 44, 33-52. [CrossRef] [PubMed] 
2. Kopp, F.; Mendell, J.T. Functional Classification and Experimental Dissection of Long Noncoding RNAs. Cell 2018, 172, 393-407. [CrossRef] [PubMed]

3. Schmitt, A.M.; Chang, H.Y. Long Noncoding RNAs in Cancer Pathways. Cancer Cell 2016, 29, $452-463$. [CrossRef] [PubMed]

4. Chen, Y.G.; Satpathy, A.T.; Chang, H.Y. Gene regulation in the immune system by long noncoding RNAs. Nat. Immunol. 2017, 18, 962-972. [CrossRef] [PubMed]

5. Bassett, A.R.; Akhtar, A.; Barlow, D.P.; Bird, A.P.; Brockdorff, N.; Duboule, D.; Ephrussi, A.; Ferguson-Smith, A.C.; Gingeras, T.R.; Haerty, W.; et al. Considerations when investigating lncRNA function in vivo. eLife 2014, 3, 03058. [CrossRef] [PubMed]

6. Esposito, R.; Bosch, N.; Lanzos, A.; Polidori, T.; Pulido-Quetglas, C.; Johnson, R. Hacking the Cancer Genome: Profiling Therapeutically Actionable Long Non-coding RNAs Using CRISPR-Cas9 Screening. Cancer Cell 2019, 35, 545-557. [CrossRef]

7. Quinn, J.J.; Chang, H.Y. Unique features of long non-coding RNA biogenesis and function. Nat. Rev. Genet. 2016, 17, 47-62. [CrossRef] [PubMed]

8. Derrien, T.; Johnson, R.; Bussotti, G.; Tanzer, A.; Djebali, S.; Tilgner, H.; Guernec, G.; Martin, D.; Merkel, A.; Knowles, D.G.; et al. The GENCODE v7 catalog of human long noncoding RNAs: Analysis of their gene structure, evolution, and expression. Genome Res. 2012, 22, 1775-1789. [CrossRef]

9. Gutschner, T.; Baas, M.; Diederichs, S. Noncoding RNA gene silencing through genomic integration of RNA destabilizing elements using zinc finger nucleases. Genome Res. 2011, 21, 1944-1954. [CrossRef]

10. Maamar, H.; Cabili, M.N.; Rinn, J.; Raj, A. linc-HOXA1 is a noncoding RNA that represses Hoxa1 transcription in cis. Genes Dev. 2013, 27, 1260-1271. [CrossRef]

11. Aparicio-Prat, E.; Arnan, C.; Sala, I.; Bosch, N.; Guigo, R.; Johnson, R. DECKO: Single-oligo, dual-CRISPR deletion of genomic elements including long non-coding RNAs. BMC Genom. 2015, 16, 846. [CrossRef] [PubMed]

12. Cong, L.; Ran, F.A.; Cox, D.; Lin, S.; Barretto, R.; Habib, N.; Hsu, P.D.; Wu, X.; Jiang, W.; Marraffini, L.A.; et al. Multiplex genome engineering using CRISPR/Cas systems. Science 2013, 339, 819-823. [CrossRef] [PubMed]

13. Shalem, O.; Sanjana, N.E.; Hartenian, E.; Shi, X.; Scott, D.A.; Mikkelson, T.; Heckl, D.; Ebert, B.L.; Root, D.E.; Doench, J.G.; et al. Genome-scale CRISPR-Cas9 knockout screening in human cells. Science 2014, 343, 84-87. [CrossRef] [PubMed]

14. Joung, J.; Engreitz, J.M.; Konermann, S.; Abudayyeh, O.O.; Verdine, V.K.; Aguet, F.; Gootenberg, J.S.; Sanjana, N.E.; Wright, J.B.; Fulco, C.P.; et al. Genome-scale activation screen identifies a lncRNA locus regulating a gene neighbourhood. Nature 2017, 548, 343-346. [CrossRef] [PubMed]

15. Liu, S.J.; Horlbeck, M.A.; Cho, S.W.; Birk, H.S.; Malatesta, M.; He, D.; Attenello, F.J.; Villalta, J.E.; Cho, M.Y.; Chen, Y.; et al. CRISPRi-based genome-scale identification of functional long noncoding RNA loci in human cells. Science 2017, 355, eaah7111. [CrossRef] [PubMed]

16. Uszczynska-Ratajczak, B.; Lagarde, J.; Frankish, A.; Guigo, R.; Johnson, R. Towards a complete map of the human long non-coding RNA transcriptome. Nat. Rev. Genet. 2018, 19, 535-548. [CrossRef] [PubMed]

17. Faghihi, M.A.; Modarresi, F.; Khalil, A.M.; Wood, D.E.; Sahagan, B.G.; Morgan, T.E.; Finch, C.E.; St Laurent, G., 3rd; Kenny, P.J.; Wahlestedt, C. Expression of a noncoding RNA is elevated in Alzheimer's disease and drives rapid feed-forward regulation of beta-secretase. Nat. Med. 2008, 14, 723-730. [CrossRef]

18. Carrieri, C.; Cimatti, L.; Biagioli, M.; Beugnet, A.; Zucchelli, S.; Fedele, S.; Pesce, E.; Ferrer, I.; Collavin, L.; Santoro, C.; et al. Long non-coding antisense RNA controls Uchl1 translation through an embedded SINEB2 repeat. Nature 2012, 491, 454-457. [CrossRef]

19. Jadaliha, M.; Gholamalamdari, O.; Tang, W.; Zhang, Y.; Petracovici, A.; Hao, Q.; Tariq, A.; Kim, T.G.; Holton, S.E.; Singh, D.K.; et al. A natural antisense lncRNA controls breast cancer progression by promoting tumor suppressor gene mRNA stability. PLoS Genet. 2018, 14, e1007802. [CrossRef]

20. Huang, B.; Song, J.H.; Cheng, Y.; Abraham, J.M.; Ibrahim, S.; Sun, Z.; Ke, X.; Meltzer, S.J. Long non-coding antisense RNA KRT7-AS is activated in gastric cancers and supports cancer cell progression by increasing KRT7 expression. Oncogene 2016, 35, 4927-4936. [CrossRef]

21. Deng, S.J.; Chen, H.Y.; Zeng, Z.; Deng, S.; Zhu, S.; Ye, Z.; He, C.; Liu, M.L.; Huang, K.; Zhong, J.X.; et al. Nutrient Stress-Dysregulated Antisense lncRNA GLS-AS Impairs GLS-Mediated Metabolism and Represses Pancreatic Cancer Progression. Cancer Res. 2019, 79, 1398-1412. [CrossRef] [PubMed] 
22. Gawronski, A.R.; Uhl, M.; Zhang, Y.; Lin, Y.Y.; Niknafs, Y.S.; Ramnarine, V.R.; Malik, R.; Feng, F.; Chinnaiyan, A.M.; Collins, C.C.; et al. MechRNA: Prediction of lncRNA mechanisms from RNA-RNA and RNA-protein interactions. Bioinformatics 2018, 34, 3101-3110. [CrossRef] [PubMed]

23. Mann, M.; Wright, P.R.; Backofen, R. IntaRNA 2.0: Enhanced and customizable prediction of RNA-RNA interactions. Nucleic Acids Res. 2017, 45, W435-W439. [CrossRef] [PubMed]

24. Cai, Z.; Cao, C.; Ji, L.; Ye, R.; Wang, D.; Xia, C.; Wang, S.; Du, Z.; Hu, N.; Yu, X.; et al. RIC-seq for global in situ profiling of RNA-RNA spatial interactions. Nature 2020. [CrossRef]

25. Nair, L.; Chung, H.; Basu, U. Regulation of long non-coding RNAs and genome dynamics by the RNA surveillance machinery. Nat. Rev. Mol. Cell Biol. 2020, 21, 123-136. [CrossRef]

26. Latos, P.A.; Pauler, F.M.; Koerner, M.V.; Senergin, H.B.; Hudson, Q.J.; Stocsits, R.R.; Allhoff, W.; Stricker, S.H.; Klement, R.M.; Warczok, K.E.; et al. Airn transcriptional overlap, but not its lncRNA products, induces imprinted Igf2r silencing. Science 2012, 338, 1469-1472. [CrossRef]

27. Tan-Wong, S.M.; Dhir, S.; Proudfoot, N.J. R-Loops Promote Antisense Transcription across the Mammalian Genome. Mol. Cell 2019, 76, 600-616.e606. [CrossRef]

28. D’Ydewalle, C.; Ramos, D.M.; Pyles, N.J.; Ng, S.Y.; Gorz, M.; Pilato, C.M.; Ling, K.; Kong, L.; Ward, A.J.; Rubin, L.L.; et al. The Antisense Transcript SMN-AS1 Regulates SMN Expression and Is a Novel Therapeutic Target for Spinal Muscular Atrophy. Neuron 2017, 93, 66-79. [CrossRef]

29. Villegas, V.E.; Zaphiropoulos, P.G. Neighboring gene regulation by antisense long non-coding RNAs. Int. J. Mol. Sci. 2015, 16, 3251-3266. [CrossRef]

30. Wang, Y.Q.; Jiang, D.M.; Hu, S.S.; Zhao, L.; Wang, L.; Yang, M.H.; Ai, M.L.; Jiang, H.J.; Han, Y.; Ding, Y.Q.; et al. SATB2-AS1 Suppresses Colorectal Carcinoma Aggressiveness by Inhibiting SATB2-Dependent Snail Transcription and Epithelial-Mesenchymal Transition. Cancer Res. 2019, 79, 3542-3556. [CrossRef]

31. Albrecht, A.S.; Orom, U.A. Bidirectional expression of long ncRNA/protein-coding gene pairs in cancer. Brief. Funct. Genom. 2016, 15, 167-173. [CrossRef] [PubMed]

32. Kapusta, A.; Feschotte, C. Volatile evolution of long noncoding RNA repertoires: Mechanisms and biological implications. Trends Genet. 2014, 30, 439-452. [CrossRef] [PubMed]

33. Musahl, A.S.; Huang, X.; Rusakiewicz, S.; Ntini, E.; Marsico, A.; Kroemer, G.; Kepp, O.; Orom, U.A. A long non-coding RNA links calreticulin-mediated immunogenic cell removal to RB1 transcription. Oncogene 2015, 34, 5046-5054. [CrossRef] [PubMed]

34. Trinklein, N.D.; Aldred, S.F.; Hartman, S.J.; Schroeder, D.I.; Otillar, R.P.; Myers, R.M. An abundance of bidirectional promoters in the human genome. Genome Res. 2004, 14, 62-66. [CrossRef] [PubMed]

35. Sigova, A.A.; Mullen, A.C.; Molinie, B.; Gupta, S.; Orlando, D.A.; Guenther, M.G.; Almada, A.E.; Lin, C.; Sharp, P.A.; Giallourakis, C.C.; et al. Divergent transcription of long noncoding RNA/mRNA gene pairs in embryonic stem cells. Proc. Natl. Acad. Sci. USA 2013, 110, 2876-2881. [CrossRef] [PubMed]

36. Hung, T.; Wang, Y.; Lin, M.F.; Koegel, A.K.; Kotake, Y.; Grant, G.D.; Horlings, H.M.; Shah, N.; Umbricht, C.; Wang, P.; et al. Extensive and coordinated transcription of noncoding RNAs within cell-cycle promoters. Nat. Genet. 2011, 43, 621-629. [CrossRef] [PubMed]

37. Wu, X.; Sharp, P.A. Divergent transcription: A driving force for new gene origination? Cell 2013, 155, 990-996. [CrossRef]

38. Beroukhim, R.; Mermel, C.H.; Porter, D.; Wei, G.; Raychaudhuri, S.; Donovan, J.; Barretina, J.; Boehm, J.S.; Dobson, J.; Urashima, M.; et al. The landscape of somatic copy-number alteration across human cancers. Nature 2010, 463, 899-905. [CrossRef]

39. Aguirre, A.J.; Meyers, R.M.; Weir, B.A.; Vazquez, F.; Zhang, C.Z.; Ben-David, U.; Cook, A.; Ha, G.; Harrington, W.F.; Doshi, M.B.; et al. Genomic Copy Number Dictates a Gene-Independent Cell Response to CRISPR/Cas9 Targeting. Cancer Discov. 2016, 6, 914-929. [CrossRef]

40. Shalem, O.; Sanjana, N.E.; Zhang, F. High-throughput functional genomics using CRISPR-Cas9. Nat. Rev. Genet. 2015, 16, 299-311. [CrossRef]

41. Horlbeck, M.A.; Gilbert, L.A.; Villalta, J.E.; Adamson, B.; Pak, R.A.; Chen, Y.; Fields, A.P.; Park, C.Y.; Corn, J.E.; Kampmann, M.; et al. Compact and highly active next-generation libraries for CRISPR-mediated gene repression and activation. eLife 2016, 5, 19760. [CrossRef] [PubMed]

42. Horlbeck, M.A.; Liu, S.J.; Chang, H.Y.; Lim, D.A.; Weissman, J.S. Fitness effects of CRISPR/Cas9-targeting of long noncoding RNA genes. Nat. Biotechnol. 2020, 38, 1-4. [CrossRef] [PubMed] 
43. Haapaniemi, E.; Botla, S.; Persson, J.; Schmierer, B.; Taipale, J. CRISPR-Cas9 genome editing induces a p53-mediated DNA damage response. Nat. Med. 2018, 24, 927-930. [CrossRef] [PubMed]

44. Ihry, R.J.; Worringer, K.A.; Salick, M.R.; Frias, E.; Ho, D.; Theriault, K.; Kommineni, S.; Chen, J.; Sondey, M.; Ye, C.; et al. p53 inhibits CRISPR-Cas9 engineering in human pluripotent stem cells. Nat. Med. 2018, 24, 939-946. [CrossRef]

45. Enache, O.M.; Rendo, V.; Abdusamad, M.; Lam, D.; Davison, D.; Pal, S.; Currimjee, N.; Hess, J.; Pantel, S.; Nag, A.; et al. Cas9 activates the p53 pathway and selects for p53-inactivating mutations. Nat. Genet. 2020, 1-7. [CrossRef] [PubMed]

46. Liu, Y.; Cao, Z.; Wang, Y.; Guo, Y.; Xu, P.; Yuan, P.; Liu, Z.; He, Y.; Wei, W. Genome-wide screening for functional long noncoding RNAs in human cells by Cas9 targeting of splice sites. Nat. Biotechnol. 2018, 36, 1203. [CrossRef]

47. Canver, M.C.; Joung, J.K.; Pinello, L. Impact of Genetic Variation on CRISPR-Cas Targeting. CRISPR J. 2018, 1, 159-170. [CrossRef]

48. Tycko, J.; Wainberg, M.; Marinov, G.K.; Ursu, O.; Hess, G.T.; Ego, B.K.; Aradhana; Li, A.; Truong, A.; Trevino, A.E.; et al. Mitigation of off-target toxicity in CRISPR-Cas9 screens for essential non-coding elements. Nat. Commun. 2019, 10, 4063. [CrossRef]

49. Meyers, R.M.; Bryan, J.G.; McFarland, J.M.; Weir, B.A.; Sizemore, A.E.; Xu, H.; Dharia, N.V.; Montgomery, P.G.; Cowley, G.S.; Pantel, S.; et al. Computational correction of copy number effect improves specificity of CRISPR-Cas9 essentiality screens in cancer cells. Nat. Genet. 2017, 49, 1779-1784. [CrossRef]

50. Wan, Y.; Kertesz, M.; Spitale, R.C.; Segal, E.; Chang, H.Y. Understanding the transcriptome through RNA structure. Nat. Rev. Genet. 2011, 12, 641-655. [CrossRef]

51. Ramanathan, M.; Porter, D.F.; Khavari, P.A. Methods to study RNA-protein interactions. Nat. Methods 2019, 16, 225-234. [CrossRef] [PubMed]

52. Lin, C.; Yang, L. Long Noncoding RNA in Cancer: Wiring Signaling Circuitry. Trends Cell Biol. 2018, 28, 287-301. [CrossRef] [PubMed]

53. Guh, C.Y.; Hsieh, Y.H.; Chu, H.P. Functions and properties of nuclear lncRNAs-from systematically mapping the interactomes of lncRNAs. J. Biomed. Sci 2020, 27, 44. [CrossRef] [PubMed]

54. Kirk, J.M.; Kim, S.O.; Inoue, K.; Smola, M.J.; Lee, D.M.; Schertzer, M.D.; Wooten, J.S.; Baker, A.R.; Sprague, D.; Collins, D.W.; et al. Functional classification of long non-coding RNAs by k-mer content. Nat. Genet. 2018, 50, 1474-1482. [CrossRef] [PubMed]

55. Carlevaro-Fita, J.; Polidori, T.; Das, M.; Navarro, C.; Zoller, T.I.; Johnson, R. Ancient exapted transposable elements promote nuclear enrichment of human long noncoding RNAs. Genome Res. 2019, 29, $208-222$. [CrossRef] [PubMed]

56. Seemann, S.E.; Mirza, A.H.; Hansen, C.; Bang-Berthelsen, C.H.; Garde, C.; Christensen-Dalsgaard, M.; Torarinsson, E.; Yao, Z.; Workman, C.T.; Pociot, F.; et al. The identification and functional annotation of RNA structures conserved in vertebrates. Genome Res. 2017, 27, 1371-1383. [CrossRef] [PubMed]

57. Thiel, B.C.; Ochsenreiter, R.; Gadekar, V.P.; Tanzer, A.; Hofacker, I.L. RNA Structure Elements Conserved between Mouse and 59 Other Vertebrates. Genes 2018, 9. [CrossRef]

58. Marin-Bejar, O.; Mas, A.M.; Gonzalez, J.; Martinez, D.; Athie, A.; Morales, X.; Galduroz, M.; Raimondi, I.; Grossi, E.; Guo, S.; et al. The human lncRNA LINC-PINT inhibits tumor cell invasion through a highly conserved sequence element. Genome Biol. 2017, 18, 202. [CrossRef]

59. Nguyen, T.M.; Kabotyanski, E.B.; Reineke, L.C.; Shao, J.; Xiong, F.; Lee, J.H.; Dubrulle, J.; Johnson, H.; Stossi, F.; Tsoi, P.S.; et al. The SINEB1 element in the long non-coding RNA Malat1 is necessary for TDP-43 proteostasis. Nucleic Acids Res. 2020, 48, 2621-2642. [CrossRef]

60. Zhang, B.; Gunawardane, L.; Niazi, F.; Jahanbani, F.; Chen, X.; Valadkhan, S. A novel RNA motif mediates the strict nuclear localization of a long noncoding RNA. Mol. Cell Biol. 2014, 34, 2318-2329. [CrossRef]

61. Zhang, B.; Mao, Y.S.; Diermeier, S.D.; Novikova, I.V.; Nawrocki, E.P.; Jones, T.A.; Lazar, Z.; Tung, C.S.; Luo, W.; Eddy, S.R.; et al. Identification and Characterization of a Class of MALAT1-like Genomic Loci. Cell Rep. 2017, 19, 1723-1738. [CrossRef] [PubMed]

62. West, J.A.; Davis, C.P.; Sunwoo, H.; Simon, M.D.; Sadreyev, R.I.; Wang, P.I.; Tolstorukov, M.Y.; Kingston, R.E. The long noncoding RNAs NEAT1 and MALAT1 bind active chromatin sites. Mol. Cell 2014, 55, 791-802. [CrossRef] [PubMed] 
63. Brown, J.A.; Bulkley, D.; Wang, J.; Valenstein, M.L.; Yario, T.A.; Steitz, T.A.; Steitz, J.A. Structural insights into the stabilization of MALAT1 noncoding RNA by a bipartite triple helix. Nat. Struct. Mol. Biol. 2014, 21, 633-640. [CrossRef] [PubMed]

64. Somarowthu, S.; Legiewicz, M.; Chillon, I.; Marcia, M.; Liu, F.; Pyle, A.M. HOTAIR forms an intricate and modular secondary structure. Mol. Cell 2015, 58, 353-361. [CrossRef]

65. Chillon, I.; Pyle, A.M. Inverted repeat Alu elements in the human lincRNA-p21 adopt a conserved secondary structure that regulates RNA function. Nucleic Acids Res. 2016, 44, 9462-9471. [CrossRef]

66. Fang, R.; Moss, W.N.; Rutenberg-Schoenberg, M.; Simon, M.D. Probing Xist RNA Structure in Cells Using Targeted Structure-Seq. PLoS Genet. 2015, 11, e1005668. [CrossRef]

67. Lubelsky, Y.; Ulitsky, I. Sequences enriched in Alu repeats drive nuclear localization of long RNAs in human cells. Nature 2018, 555, 107-111. [CrossRef]

68. Wilusz, J.E.; JnBaptiste, C.K.; Lu, L.Y.; Kuhn, C.D.; Joshua-Tor, L.; Sharp, P.A. A triple helix stabilizes the 3' ends of long noncoding RNAs that lack poly(A) tails. Genes Dev. 2012, 26, 2392-2407. [CrossRef]

69. Brown, J.A.; Valenstein, M.L.; Yario, T.A.; Tycowski, K.T.; Steitz, J.A. Formation of triple-helical structures by the 3'-end sequences of MALAT1 and MENbeta noncoding RNAs. Proc. Natl. Acad. Sci USA 2012, 109, 19202-19207. [CrossRef]

70. Gong, C.; Maquat, L.E. lncRNAs transactivate STAU1-mediated mRNA decay by duplexing with 3' UTRs via Alu elements. Nature 2011, 470, 284-288. [CrossRef]

71. Hacisuleyman, E.; Goff, L.A.; Trapnell, C.; Williams, A.; Henao-Mejia, J.; Sun, L.; McClanahan, P.; Hendrickson, D.G.; Sauvageau, M.; Kelley, D.R.; et al. Topological organization of multichromosomal regions by the long intergenic noncoding RNA Firre. Nat. Struct. Mol. Biol. 2014, 21, 198-206. [CrossRef] [PubMed]

72. Shukla, C.J.; McCorkindale, A.L.; Gerhardinger, C.; Korthauer, K.D.; Cabili, M.N.; Shechner, D.M.; Irizarry, R.A.; Maass, P.G.; Rinn, J.L. High-throughput identification of RNA nuclear enrichment sequences. EMBO J. 2018, 37, 98452. [CrossRef] [PubMed]

73. Yin, Y.; Lu, J.Y.; Zhang, X.; Shao, W.; Xu, Y.; Li, P.; Hong, Y.; Cui, L.; Shan, G.; Tian, B.; et al. U1 snRNP regulates chromatin retention of noncoding RNAs. Nature 2020, 580, 147-150. [CrossRef] [PubMed]

74. Gandhi, M.; Caudron-Herger, M.; Diederichs, S. RNA motifs and combinatorial prediction of interactions, stability and localization of noncoding RNAs. Nat. Struct. Mol. Biol. 2018, 25, 1070-1076. [CrossRef] [PubMed]

75. Chu, C.; Zhang, Q.C.; da Rocha, S.T.; Flynn, R.A.; Bharadwaj, M.; Calabrese, J.M.; Magnuson, T.; Heard, E.; Chang, H.Y. Systematic discovery of Xist RNA binding proteins. Cell 2015, 161, 404-416. [CrossRef] [PubMed]

76. Lee, S.; Kopp, F.; Chang, T.C.; Sataluri, A.; Chen, B.; Sivakumar, S.; Yu, H.; Xie, Y.; Mendell, J.T. Noncoding RNA NORAD Regulates Genomic Stability by Sequestering PUMILIO Proteins. Cell 2016, 164, 69-80. [CrossRef] [PubMed]

77. Tichon, A.; Gil, N.; Lubelsky, Y.; Havkin Solomon, T.; Lemze, D.; Itzkovitz, S.; Stern-Ginossar, N.; Ulitsky, I. A conserved abundant cytoplasmic long noncoding RNA modulates repression by Pumilio proteins in human cells. Nat. Commun. 2016, 7, 12209. [CrossRef]

78. Schmidt, K.; Weidmann, C.A.; Hilimire, T.A.; Yee, E.; Hatfield, B.M.; Schneekloth, J.S., Jr.; Weeks, K.M.; Novina, C.D. Targeting the Oncogenic Long Non-coding RNA SLNCR1 by Blocking Its Sequence-Specific Binding to the Androgen Receptor. Cell Rep. 2020, 30, 541-554. [CrossRef]

79. Yang, L.; Lin, C.; Jin, C.; Yang, J.C.; Tanasa, B.; Li, W.; Merkurjev, D.; Ohgi, K.A.; Meng, D.; Zhang, J.; et al. lncRNA-dependent mechanisms of androgen-receptor-regulated gene activation programs. Nature 2013, 500, 598-602. [CrossRef]

80. Zhang, A.; Zhao, J.C.; Kim, J.; Fong, K.W.; Yang, Y.A.; Chakravarti, D.; Mo, Y.Y.; Yu, J. LncRNA HOTAIR Enhances the Androgen-Receptor-Mediated Transcriptional Program and Drives Castration-Resistant Prostate Cancer. Cell Rep. 2015, 13, 209-221. [CrossRef]

81. Carlevaro-Fita, J.; Johnson, R. Global Positioning System: Understanding Long Noncoding RNAs through Subcellular Localization. Mol. Cell 2019, 73, 869-883. [CrossRef] [PubMed]

82. Yao, R.W.; Wang, Y.; Chen, L.L. Cellular functions of long noncoding RNAs. Nat. Cell Biol. 2019, $21,542-551$. [CrossRef] [PubMed]

83. Taliaferro, J.M. Classical and emerging techniques to identify and quantify localized RNAs. Wiley Interdiscip. Rev. RNA 2019, 10, e1542. [CrossRef] [PubMed] 
84. Raj, A.; Bogaard, P.V.D.; Rifkin, S.A.; van Oudenaarden, A.; Tyagi, S. Imaging individual mRNA molecules using multiple singly labeled probes. Nat. Methods 2008, 5, 877-879. [CrossRef] [PubMed]

85. Samacoits, A.; Chouaib, R.; Safieddine, A.; Traboulsi, A.M.; Ouyang, W.; Zimmer, C.; Peter, M.; Bertrand, E.; Walter, T.; Mueller, F. A computational framework to study sub-cellular RNA localization. Nat. Commun. 2018, 9, 4584. [CrossRef]

86. Larson, D.R.; Zenklusen, D.; Wu, B.; Chao, J.A.; Singer, R.H. Real-time observation of transcription initiation and elongation on an endogenous yeast gene. Science 2011, 332, 475-478. [CrossRef]

87. Wu, B.; Chao, J.A.; Singer, R.H. Fluorescence fluctuation spectroscopy enables quantitative imaging of single mRNAs in living cells. Biophys. J. 2012, 102, 2936-2944. [CrossRef]

88. Batra, R.; Nelles, D.A.; Pirie, E.; Blue, S.M.; Marina, R.J.; Wang, H.; Chaim, I.A.; Thomas, J.D.; Zhang, N.; Nguyen, V.; et al. Elimination of Toxic Microsatellite Repeat Expansion RNA by RNA-Targeting Cas9. Cell 2017, 170, 899-912. [CrossRef]

89. Nelles, D.A.; Fang, M.Y.; O'Connell, M.R.; Xu, J.L.; Markmiller, S.J.; Doudna, J.A.; Yeo, G.W. Programmable RNA Tracking in Live Cells with CRISPR/Cas9. Cell 2016, 165, 488-496. [CrossRef]

90. Abudayyeh, O.O.; Gootenberg, J.S.; Essletzbichler, P.; Han, S.; Joung, J.; Belanto, J.J.; Verdine, V.; Cox, D.B.T.; Kellner, M.J.; Regev, A.; et al. RNA targeting with CRISPR-Cas13. Nature 2017, 550, 280-284. [CrossRef]

91. Yang, L.Z.; Wang, Y.; Li, S.Q.; Yao, R.W.; Luan, P.F.; Wu, H.; Carmichael, G.G.; Chen, L.L. Dynamic Imaging of RNA in Living Cells by CRISPR-Cas13 Systems. Mol. Cell 2019, 76, 981-997. [CrossRef] [PubMed]

92. Zuckerman, B.; Ulitsky, I. Predictive models of subcellular localization of long RNAs. RNA 2019, 25, 557-572. [CrossRef] [PubMed]

93. Zhang, L.; Yang, Z.; Trottier, J.; Barbier, O.; Wang, L. Long noncoding RNA MEG3 induces cholestatic liver injury by interaction with PTBP1 to facilitate shp mRNA decay. Hepatology 2017, 65, 604-615. [CrossRef] [PubMed]

94. Mondal, T.; Subhash, S.; Vaid, R.; Enroth, S.; Uday, S.; Reinius, B.; Mitra, S.; Mohammed, A.; James, A.R.; Hoberg, E.; et al. MEG3 long noncoding RNA regulates the TGF-beta pathway genes through formation of RNA-DNA triplex structures. Nat. Commun. 2015, 6, 7743. [CrossRef] [PubMed]

95. Clark, M.B.; Johnston, R.L.; Inostroza-Ponta, M.; Fox, A.H.; Fortini, E.; Moscato, P.; Dinger, M.E.; Mattick, J.S. Genome-wide analysis of long noncoding RNA stability. Genome Res. 2012, 22, 885-898. [CrossRef]

96. Tani, H.; Mizutani, R.; Salam, K.A.; Tano, K.; Ijiri, K.; Wakamatsu, A.; Isogai, T.; Suzuki, Y.; Akimitsu, N. Genome-wide determination of RNA stability reveals hundreds of short-lived noncoding transcripts in mammals. Genome Res. 2012, 22, 947-956. [CrossRef] [PubMed]

97. Ayupe, A.C.; Tahira, A.C.; Camargo, L.; Beckedorff, F.C.; Verjovski-Almeida, S.; Reis, E.M. Global analysis of biogenesis, stability and sub-cellular localization of lncRNAs mapping to intragenic regions of the human genome. RNA Biol. 2015, 12, 877-892. [CrossRef]

98. Li, W.; Notani, D.; Rosenfeld, M.G. Enhancers as non-coding RNA transcription units: Recent insights and future perspectives. Nat. Rev. Genet. 2016, 17, 207-223. [CrossRef]

99. Engreitz, J.M.; Sirokman, K.; McDonel, P.; Shishkin, A.A.; Surka, C.; Russell, P.; Grossman, S.R.; Chow, A.Y.; Guttman, M.; Lander, E.S. RNA-RNA interactions enable specific targeting of noncoding RNAs to nascent Pre-mRNAs and chromatin sites. Cell 2014, 159, 188-199. [CrossRef]

100. Guttman, M.; Amit, I.; Garber, M.; French, C.; Lin, M.F.; Feldser, D.; Huarte, M.; Zuk, O.; Carey, B.W.; Cassady, J.P.; et al. Chromatin signature reveals over a thousand highly conserved large non-coding RNAs in mammals. Nature 2009, 458, 223-227. [CrossRef]

101. Haerty, W.; Ponting, C.P. Unexpected selection to retain high GC content and splicing enhancers within exons of multiexonic lncRNA loci. RNA 2015, 21, 333-346. [CrossRef] [PubMed]

102. Washietl, S.; Kellis, M.; Garber, M. Evolutionary dynamics and tissue specificity of human long noncoding RNAs in six mammals. Genome Res. 2014, 24, 616-628. [CrossRef] [PubMed]

103. Cabili, M.N.; Trapnell, C.; Goff, L.; Koziol, M.; Tazon-Vega, B.; Regev, A.; Rinn, J.L. Integrative annotation of human large intergenic noncoding RNAs reveals global properties and specific subclasses. Genes Dev. 2011, 25, 1915-1927. [CrossRef] [PubMed]

104. Dinger, M.E.; Amaral, P.P.; Mercer, T.R.; Pang, K.C.; Bruce, S.J.; Gardiner, B.B.; Askarian-Amiri, M.E.; Ru, K.; Solda, G.; Simons, C.; et al. Long noncoding RNAs in mouse embryonic stem cell pluripotency and differentiation. Genome Res. 2008, 18, 1433-1445. [CrossRef] 
105. Mercer, T.R.; Dinger, M.E.; Sunkin, S.M.; Mehler, M.F.; Mattick, J.S. Specific expression of long noncoding RNAs in the mouse brain. Proc. Natl. Acad. Sci. USA 2008, 105, 716-721. [CrossRef]

106. Wang, P.; Xue, Y.; Han, Y.; Lin, L.; Wu, C.; Xu, S.; Jiang, Z.; Xu, J.; Liu, Q.; Cao, X. The STAT3-binding long noncoding RNA lnc-DC controls human dendritic cell differentiation. Science 2014, 344, 310-313. [CrossRef]

107. Gomez, J.A.; Wapinski, O.L.; Yang, Y.W.; Bureau, J.F.; Gopinath, S.; Monack, D.M.; Chang, H.Y.; Brahic, M.; Kirkegaard, K. The NeST long ncRNA controls microbial susceptibility and epigenetic activation of the interferon-gamma locus. Cell 2013, 152, 743-754. [CrossRef]

108. Willingham, A.T.; Orth, A.P.; Batalov, S.; Peters, E.C.; Wen, B.G.; Aza-Blanc, P.; Hogenesch, J.B.; Schultz, P.G. A strategy for probing the function of noncoding RNAs finds a repressor of NFAT. Science 2005, 309, 1570-1573. [CrossRef]

109. Sharma, S.; Findlay, G.M.; Bandukwala, H.S.; Oberdoerffer, S.; Baust, B.; Li, Z.; Schmidt, V.; Hogan, P.G.; Sacks, D.B.; Rao, A. Dephosphorylation of the nuclear factor of activated T cells (NFAT) transcription factor is regulated by an RNA-protein scaffold complex. Proc. Natl. Acad. Sci. USA 2011, 108, 11381-11386. [CrossRef]

110. Hezroni, H.; Koppstein, D.; Schwartz, M.G.; Avrutin, A.; Bartel, D.P.; Ulitsky, I. Principles of long noncoding RNA evolution derived from direct comparison of transcriptomes in 17 species. Cell Rep. 2015, 11, 1110-1122. [CrossRef]

111. Kutter, C.; Watt, S.; Stefflova, K.; Wilson, M.D.; Goncalves, A.; Ponting, C.P.; Odom, D.T.; Marques, A.C. Rapid turnover of long noncoding RNAs and the evolution of gene expression. PLoS Genet. 2012, 8, e1002841. [CrossRef] [PubMed]

112. Zhao, J.; Sun, B.K.; Erwin, J.A.; Song, J.J.; Lee, J.T. Polycomb proteins targeted by a short repeat RNA to the mouse $X$ chromosome. Science 2008, 322, 750-756. [CrossRef] [PubMed]

113. Lu, Z.; Zhang, Q.C.; Lee, B.; Flynn, R.A.; Smith, M.A.; Robinson, J.T.; Davidovich, C.; Gooding, A.R.; Goodrich, K.J.; Mattick, J.S.; et al. RNA Duplex Map in Living Cells Reveals Higher-Order Transcriptome Structure. Cell 2016, 165, 1267-1279. [CrossRef] [PubMed]

114. Yamazaki, T.; Souquere, S.; Chujo, T.; Kobelke, S.; Chong, Y.S.; Fox, A.H.; Bond, C.S.; Nakagawa, S.; Pierron, G.; Hirose, T. Functional Domains of NEAT1 Architectural lncRNA Induce Paraspeckle Assembly through Phase Separation. Mol. Cell 2018, 70, 1038-1053. [CrossRef]

115. Ulitsky, I. Evolution to the rescue: Using comparative genomics to understand long non-coding RNAs. Nat. Rev. Genet. 2016, 17, 601-614. [CrossRef]

116. Goto, T.; Monk, M. Regulation of X-chromosome inactivation in development in mice and humans. Microbiol. Mol. Biol. Rev. 1998, 62, 362-378. [CrossRef]

117. Sasaki, Y.T.; Ideue, T.; Sano, M.; Mituyama, T.; Hirose, T. MENepsilon/beta noncoding RNAs are essential for structural integrity of nuclear paraspeckles. Proc. Natl. Acad. Sci. USA 2009, 106, 2525-2530. [CrossRef]

118. Cornelis, G.; Souquere, S.; Vernochet, C.; Heidmann, T.; Pierron, G. Functional conservation of the lncRNA NEAT1 in the ancestrally diverged marsupial lineage: Evidence for NEAT1 expression and associated paraspeckle assembly during late gestation in the opossum Monodelphis domestica. RNA Biol. 2016, 13, 826-836. [CrossRef]

119. Guo, C.J.; Ma, X.K.; Xing, Y.H.; Zheng, C.C.; Xu, Y.F.; Shan, L.; Zhang, J.; Wang, S.; Wang, Y.; Carmichael, G.G.; et al. Distinct Processing of lncRNAs Contributes to Non-conserved Functions in Stem Cells. Cell 2020. [CrossRef]

120. Rinn, J.L.; Kertesz, M.; Wang, J.K.; Squazzo, S.L.; Xu, X.; Brugmann, S.A.; Goodnough, L.H.; Helms, J.A.; Farnham, P.J.; Segal, E.; et al. Functional demarcation of active and silent chromatin domains in human HOX loci by noncoding RNAs. Cell 2007, 129, 1311-1323. [CrossRef]

121. Schorderet, P.; Duboule, D. Structural and functional differences in the long non-coding RNA hotair in mouse and human. PLoS Genet. 2011, 7, e1002071. [CrossRef] [PubMed]

122. Li, L.; Liu, B.; Wapinski, O.L.; Tsai, M.C.; Qu, K.; Zhang, J.; Carlson, J.C.; Lin, M.; Fang, F.; Gupta, R.A.; et al. Targeted disruption of Hotair leads to homeotic transformation and gene derepression. Cell Rep. 2013, 5, 3-12. [CrossRef] [PubMed]

123. Amandio, A.R.; Necsulea, A.; Joye, E.; Mascrez, B.; Duboule, D. Hotair Is Dispensible for Mouse Development. PLoS Genet. 2016, 12, e1006232. [CrossRef] [PubMed]

124. Selleri, L.; Bartolomei, M.S.; Bickmore, W.A.; He, L.; Stubbs, L.; Reik, W.; Barsh, G.S. A Hox-Embedded Long Noncoding RNA: Is It All Hot Air? PLoS Genet. 2016, 12, e1006485. [CrossRef] [PubMed] 
125. Yan, X.; Hu, Z.; Feng, Y.; Hu, X.; Yuan, J.; Zhao, S.D.; Zhang, Y.; Yang, L.; Shan, W.; He, Q.; et al. Comprehensive Genomic Characterization of Long Non-coding RNAs across Human Cancers. Cancer Cell 2015, 28, 529-540. [CrossRef] [PubMed]

126. Chiu, H.S.; Somvanshi, S.; Patel, E.; Chen, T.W.; Singh, V.P.; Zorman, B.; Patil, S.L.; Pan, Y.; Chatterjee, S.S.; Cancer Genome Atlas Research, N.; et al. Pan-Cancer Analysis of lncRNA Regulation Supports Their Targeting of Cancer Genes in Each Tumor Context. Cell Rep. 2018, 23, 297-312. [CrossRef]

127. Hu, X.; Feng, Y.; Zhang, D.; Zhao, S.D.; Hu, Z.; Greshock, J.; Zhang, Y.; Yang, L.; Zhong, X.; Wang, L.P.; et al. A functional genomic approach identifies FAL1 as an oncogenic long noncoding RNA that associates with BMI1 and represses p21 expression in cancer. Cancer Cell 2014, 26, 344-357. [CrossRef]

128. Ling, H.; Spizzo, R.; Atlasi, Y.; Nicoloso, M.; Shimizu, M.; Redis, R.S.; Nishida, N.; Gafa, R.; Song, J.; Guo, Z.; et al. CCAT2, a novel noncoding RNA mapping to 8q24, underlies metastatic progression and chromosomal instability in colon cancer. Genome Res. 2013, 23, 1446-1461. [CrossRef]

129. Nguyen, Q.; Carninci, P. Expression Specificity of Disease-Associated lncRNAs: Toward Personalized Medicine. Curr. Top. Microbiol. Immunol. 2016, 394, 237-258. [CrossRef]

130. Ching, T.; Peplowska, K.; Huang, S.; Zhu, X.; Shen, Y.; Molnar, J.; Yu, H.; Tiirikainen, M.; Fogelgren, B.; Fan, R.; et al. Pan-Cancer Analyses Reveal Long Intergenic Non-Coding RNAs Relevant to Tumor Diagnosis, Subtyping and Prognosis. EBioMedicine 2016, 7, 62-72. [CrossRef]

131. Ali, M.M.; Akhade, V.S.; Kosalai, S.T.; Subhash, S.; Statello, L.; Meryet-Figuiere, M.; Abrahamsson, J.; Mondal, T.; Kanduri, C. PAN-cancer analysis of S-phase enriched lncRNAs identifies oncogenic drivers and biomarkers. Nat. Commun. 2018, 9, 883. [CrossRef] [PubMed]

132. Engreitz, J.M.; Haines, J.E.; Perez, E.M.; Munson, G.; Chen, J.; Kane, M.; McDonel, P.E.; Guttman, M.; Lander, E.S. Local regulation of gene expression by lncRNA promoters, transcription and splicing. Nature 2016, 539, 452-455. [CrossRef] [PubMed]

133. Zhang, Y.; He, Q.; Hu, Z.; Feng, Y.; Fan, L.; Tang, Z.; Yuan, J.; Shan, W.; Li, C.; Hu, X.; et al. Long noncoding RNA LINP1 regulates repair of DNA double-strand breaks in triple-negative breast cancer. Nat. Struct. Mol. Biol. 2016, 23, 522-530. [CrossRef] [PubMed]

134. Kim, J.; Piao, H.L.; Kim, B.J.; Yao, F.; Han, Z.; Wang, Y.; Xiao, Z.; Siverly, A.N.; Lawhon, S.E.; Ton, B.N.; et al. Long noncoding RNA MALAT1 suppresses breast cancer metastasis. Nat. Genet. 2018, 50, 1705-1715. [CrossRef] [PubMed]

135. Lin, A.; Hu, Q.; Li, C.; Xing, Z.; Ma, G.; Wang, C.; Li, J.; Ye, Y.; Yao, J.; Liang, K.; et al. The LINK-A lncRNA interacts with PtdIns(3,4,5)P3 to hyperactivate AKT and confer resistance to AKT inhibitors. Nat. Cell Biol. 2017, 19, 238-251. [CrossRef]

136. Hu, Q.; Ye, Y.; Chan, L.C.; Li, Y.; Liang, K.; Lin, A.; Egranov, S.D.; Zhang, Y.; Xia, W.; Gong, J.; et al. Oncogenic lncRNA downregulates cancer cell antigen presentation and intrinsic tumor suppression. Nat. Immunol. 2019, 20, 835-851. [CrossRef]

137. Yeh, E.; Cunningham, M.; Arnold, H.; Chasse, D.; Monteith, T.; Ivaldi, G.; Hahn, W.C.; Stukenberg, P.T.; Shenolikar, S.; Uchida, T.; et al. A signalling pathway controlling c-Myc degradation that impacts oncogenic transformation of human cells. Nat. Cell Biol. 2004, 6, 308-318. [CrossRef]

138. Tseng, Y.Y.; Moriarity, B.S.; Gong, W.; Akiyama, R.; Tiwari, A.; Kawakami, H.; Ronning, P.; Reuland, B.; Guenther, K.; Beadnell, T.C.; et al. PVT1 dependence in cancer with MYC copy-number increase. Nature 2014, 512, 82-86. [CrossRef]

139. Jin, K.; Wang, S.; Zhang, Y.; Xia, M.; Mo, Y.; Li, X.; Li, G.; Zeng, Z.; Xiong, W.; He, Y. Long non-coding RNA PVT1 interacts with MYC and its downstream molecules to synergistically promote tumorigenesis. Cell Mol. Life Sci. 2019, 76, 4275-4289. [CrossRef]

140. Zhang, B.; Arun, G.; Mao, Y.S.; Lazar, Z.; Hung, G.; Bhattacharjee, G.; Xiao, X.; Booth, C.J.; Wu, J.; Zhang, C.; et al. The lncRNA Malat1 is dispensable for mouse development but its transcription plays a cis-regulatory role in the adult. Cell Rep. 2012, 2, 111-123. [CrossRef]

141. Nakagawa, S.; Ip, J.Y.; Shioi, G.; Tripathi, V.; Zong, X.; Hirose, T.; Prasanth, K.V. Malat1 is not an essential component of nuclear speckles in mice. RNA 2012, 18, 1487-1499. [CrossRef] [PubMed]

142. Arun, G.; Diermeier, S.; Akerman, M.; Chang, K.C.; Wilkinson, J.E.; Hearn, S.; Kim, Y.; MacLeod, A.R.; Krainer, A.R.; Norton, L.; et al. Differentiation of mammary tumors and reduction in metastasis upon Malat1 lncRNA loss. Genes Dev. 2016, 30, 34-51. [CrossRef] [PubMed] 
143. Sun, Y.; Ma, L. New Insights into Long Non-Coding RNA MALAT1 in Cancer and Metastasis. Cancers 2019, 11, 216. [CrossRef]

144. Miller, M.A.; Olivas, W.M. Roles of Puf proteins in mRNA degradation and translation. Wiley Interdiscip. Rev. RNA 2011, 2, 471-492. [CrossRef]

145. Huarte, M.; Guttman, M.; Feldser, D.; Garber, M.; Koziol, M.J.; Kenzelmann-Broz, D.; Khalil, A.M.; Zuk, O.; Amit, I.; Rabani, M.; et al. A large intergenic noncoding RNA induced by p53 mediates global gene repression in the p53 response. Cell 2010, 142, 409-419. [CrossRef] [PubMed]

146. Dimitrova, N.; Zamudio, J.R.; Jong, R.M.; Soukup, D.; Resnick, R.; Sarma, K.; Ward, A.J.; Raj, A.; Lee, J.T.; Sharp, P.A.; et al. LincRNA-p21 activates p21 in cis to promote Polycomb target gene expression and to enforce the G1/S checkpoint. Mol. Cell 2014, 54, 777-790. [CrossRef]

147. Allen, M.A.; Andrysik, Z.; Dengler, V.L.; Mellert, H.S.; Guarnieri, A.; Freeman, J.A.; Sullivan, K.D.; Galbraith, M.D.; Luo, X.; Kraus, W.L.; et al. Global analysis of p53-regulated transcription identifies its direct targets and unexpected regulatory mechanisms. eLife 2014, 3, 02200. [CrossRef]

148. Lin, M.F.; Jungreis, I.; Kellis, M. PhyloCSF: A comparative genomics method to distinguish protein coding and non-coding regions. Bioinformatics 2011, 27, 275-282. [CrossRef]

149. Goyal, A.; Myacheva, K.; Gross, M.; Klingenberg, M.; Duran Arque, B.; Diederichs, S. Challenges of CRISPR/Cas9 applications for long non-coding RNA genes. Nucleic Acids Res. 2017, 45, e12. [CrossRef]

150. Xu, S.; Kim, J.; Tang, Q.; Chen, Q.; Liu, J.; Xu, Y.; Fu, X. CAS9 is a genome mutator by directly disrupting DNA-PK dependent DNA repair pathway. Protein Cell 2020. [CrossRef]

151. Anderson, K.M.; Anderson, D.M.; McAnally, J.R.; Shelton, J.M.; Bassel-Duby, R.; Olson, E.N. Transcription of the non-coding RNA upperhand controls Hand2 expression and heart development. Nature 2016, 539, 433-436. [CrossRef] [PubMed]

152. Kambara, H.; Gunawardane, L.; Zebrowski, E.; Kostadinova, L.; Jobava, R.; Krokowski, D.; Hatzoglou, M.; Anthony, D.D.; Valadkhan, S. Regulation of Interferon-Stimulated Gene BST2 by a lncRNA Transcribed from a Shared Bidirectional Promoter. Front. Immunol. 2014, 5, 676. [CrossRef] [PubMed]

153. Hagedorn, P.H.; Pontoppidan, M.; Bisgaard, T.S.; Berrera, M.; Dieckmann, A.; Ebeling, M.; Moller, M.R.; Hudlebusch, H.; Jensen, M.L.; Hansen, H.F.; et al. Identifying and avoiding off-target effects of RNase H-dependent antisense oligonucleotides in mice. Nucleic Acids Res. 2018, 46, 5366-5380. [CrossRef] [PubMed]

154. Gutschner, T.; Hammerle, M.; Eissmann, M.; Hsu, J.; Kim, Y.; Hung, G.; Revenko, A.; Arun, G.; Stentrup, M.; Gross, M.; et al. The noncoding RNA MALAT1 is a critical regulator of the metastasis phenotype of lung cancer cells. Cancer Res. 2013, 73, 1180-1189. [CrossRef]

155. Lee, J.S.; Mendell, J.T. Antisense-Mediated Transcript Knockdown Triggers Premature Transcription Termination. Mol. Cell 2020, 77, 1044-1054. [CrossRef]

156. Lai, F.; Damle, S.S.; Ling, K.K.; Rigo, F. Directed RNase HCleavage of Nascent Transcripts Causes Transcription Termination. Mol. Cell 2020, 77, 1032-1043. [CrossRef]

157. Yin, Y.; Yan, P.; Lu, J.; Song, G.; Zhu, Y.; Li, Z.; Zhao, Y.; Shen, B.; Huang, X.; Zhu, H.; et al. Opposing Roles for the lncRNA Haunt and Its Genomic Locus in Regulating HOXA Gene Activation during Embryonic Stem Cell Differentiation. Cell Stem Cell 2015, 16, 504-516. [CrossRef]

158. Sauvageau, M.; Goff, L.A.; Lodato, S.; Bonev, B.; Groff, A.F.; Gerhardinger, C.; Sanchez-Gomez, D.B.; Hacisuleyman, E.; Li, E.; Spence, M.; et al. Multiple knockout mouse models reveal lincRNAs are required for life and brain development. eLife 2013, 2, 1749. [CrossRef]

159. Grote, P.; Wittler, L.; Hendrix, D.; Koch, F.; Wahrisch, S.; Beisaw, A.; Macura, K.; Blass, G.; Kellis, M.; Werber, M.; et al. The tissue-specific lncRNA Fendrr is an essential regulator of heart and body wall development in the mouse. Dev. Cell 2013, 24, 206-214. [CrossRef]

160. Feng, J.; Bi, C.; Clark, B.S.; Mady, R.; Shah, P.; Kohtz, J.D. The Evf-2 noncoding RNA is transcribed from the Dlx-5/6 ultraconserved region and functions as a Dlx-2 transcriptional coactivator. Genes Dev. 2006, 20, 1470-1484. [CrossRef]

161. Bond, A.M.; Vangompel, M.J.; Sametsky, E.A.; Clark, M.F.; Savage, J.C.; Disterhoft, J.F.; Kohtz, J.D. Balanced gene regulation by an embryonic brain ncRNA is critical for adult hippocampal GABA circuitry. Nat. Neurosci. 2009, 12, 1020-1027. [CrossRef] [PubMed] 
162. Berghoff, E.G.; Clark, M.F.; Chen, S.; Cajigas, I.; Leib, D.E.; Kohtz, J.D. Evf2 (Dlx6as) lncRNA regulates ultraconserved enhancer methylation and the differential transcriptional control of adjacent genes. Development 2013, 140, 4407-4416. [CrossRef] [PubMed]

163. Stojic, L.; Lun, A.T.L.; Mangei, J.; Mascalchi, P.; Quarantotti, V.; Barr, A.R.; Bakal, C.; Marioni, J.C.; Gergely, F.; Odom, D.T. Specificity of RNAi, LNA and CRISPRi as loss-of-function methods in transcriptional analysis. Nucleic Acids Res. 2018, 46, 5950-5966. [CrossRef] [PubMed]

C 2020 by the authors. Licensee MDPI, Basel, Switzerland. This article is an open access article distributed under the terms and conditions of the Creative Commons Attribution (CC BY) license (http://creativecommons.org/licenses/by/4.0/). 